\title{
Using remote sensing to characterize riparian vegetation: a review of available tools and perspectives for managers
}

Leo Huylenbroeck ${ }^{1 *^{+}}$, Marianne Laslier $^{2 *}$, Simon Dufour ${ }^{3}$, Blandine Georges $^{1}$, Philippe Lejeune ${ }^{1}$, Adrien Michez ${ }^{1}$

${ }^{*}$ Contributed equally

+Corresponding author (leo.huylenbroeck@uliege.be)

${ }^{1}$ ULiège, Gembloux Agro-Bio Tech, TERRA Teaching and Research Centre (Forest is Life). 2, Passage des Déportés, 5030 Gembloux, Belgium

${ }^{2}$ INRAE centre de Lyon Grenoble Auvergne Rhône-Alpes. 5 Rue de la Doua, 69100 Villeurbanne, France

${ }^{3}$ Université Rennes 2 LETG Rennes, Place du Recteur Henri Le Moal 35043 Rennes cedex, France 


\section{Research Highlights}

- Review shows diverse approaches and objectives for mapping riparian vegetation

- Scale of observation, remote sensing data and mapped features are strongly related

- Finer spatial and temporal resolution will renew large scale and diachronic analyses

- We discuss the challenges of conveying remote sensing tools to managers

- Open access tools and co-construction with managers foster technology transfer 


\begin{abstract}
1 Riparian vegetation is a central component of the hydrosystem. As such, it is often subject to 2 management practices that aim to influence its ecological, hydraulic or hydrological functions.

3 Remote sensing has the potential to improve knowledge and management of riparian vegetation by 4 providing cost-effective and spatially continuous data over wide extents. The objectives of this review were twofold: to provide an overview of the use of remote sensing in riparian vegetation studies and to discuss the transferability of remote sensing tools from scientists to managers. We systematically reviewed the scientific literature (428 articles) to identify the objectives and remote sensing data used to characterize riparian vegetation. Overall, results highlight a strong relationship between the tools used, the features of riparian vegetation extracted and the mapping extent. Very high-resolution data are rarely used for rivers longer than than $100 \mathrm{~km}$, especially when mapping species composition. Multi-temporality is central in remote sensing riparian studies, but authors use only aerial photographs and relatively coarse resolution satellite images for diachronic analyses. Some remote sensing approaches have reached an operational level and are now used for management purposes. Overall, new opportunities will arise with the increased availability of very high-resolution data in understudied or data-scarce regions, for large extents and as time series. To transfer remote sensing approaches to riparian managers, we suggest mutualizing achievements by producting open-access and robust tools. These tools will then have to be adapted to each specific project, in collaboration with managers.
\end{abstract}

\title{
19 Keywords
}




\section{Introduction}

At the interface between terrestrial and aquatic biota, riparian vegetation is a central element in the hydrosystem, where it plays many ecological roles and interacts with all hydrosystem components (Naiman et al., 2005). In a broad sense, riparian vegetation corresponds to all vegetation types that grow within the area influenced by a river network (Naiman and Décamps, 1997).

Despite covering a relatively small area, riparian vegetation provides many ecosystem services related to river flow (Dixon et al., 2016), sedimentary processes (Zaimes et al., 2004), biodiversity (Naiman and Décamps, 1997), water quality (Honey-Rosés et al., 2013, Brogna et al., 2018), cultural value (Décamps, 2001, Klein et al., 2015, Vollmer et al., 2015). However, riparian ecosystems experience multiple pressures (e.g. land use, water diversion, modified flood regime) (Stella and Bendix, 2019) and have been severely altered in many regions of the world, for example in Western Europe (Hughes et al., 2012), southwestern North America (Poff et al., 2011), in the Murray-Darling Basin in Australia (Mac Nally et al., 2011) or in South Africa (Holmes et al, 2005). Consequently, riparian vegetation is often the focus of management practices, including restoration or rehabilitation measures (Dufour and Piégay, 2009; González et al., 2015; Capon and Pettit, 2018), buffer implementation (Lee et al., 2004) or repeated maintenance operations such as wood removal (Piégay and Landon, 1997; Wohl et al., 2016).

In this context, management practices must be based on accurate and up-to-date information about the state of riparian vegetation (National Research Council, 2002). Regional or national programs have thus been established in many countries to monitor the health of riparian ecosystems. Examples include southern Belgium (Debruxelles et al, 2009), Spain and more generally the European Union in the frame of the Water Framework Directive (Munné et al., 2003, Willaarts et al., 2014), Australia with the South East Queensland Healthy Waterways Partnership (Bunn et al., 2010) or the monitoring of riparian condition in several National Parks in North America (Starkey, 2016). Dense sampling schemes can help target and implement management practices (Landon et al., 1998; 
Beechie et al., 2008) or assess their effectiveness (González et al., 2015). However, due to the spatial arrangement, dynamism and inaccessibility of riparian ecosystems, data acquisition in the field can be labor-intensive, especially for large areas (i.e. more than $100 \mathrm{~km}$ of a river) (Johansen et al., 2007). It is thus difficult to sample densly in the field, and the density or the extent of observations must be reduced. This can be problematic, because river scientists argue that small scale or discontinuous observations are inadequate to understand spatially continuous processes that occur at large spatial scales (Fausch et al., 2002; Marcus and Fonstad, 2008; see also Tabacchi et al., 1998 or Palmquist et al., 2018 for examples related to riparian vegetation).

Remote sensing provides the ability to acquire continuous data over large extents. In the past few decades, the continued development of sensors, vectors and computational power has fueled the development of applications in environmental science (Anderson and Gaston, 2013; Wulder et al., 2012). The positive contribution of remote sensing to the management of natural resources is adressed by many articles related to river or riparian management (Carbonneau and Piégay, 2012, Dufour et al., 2012). This is not only a theoretical issue as is it regularly raised by riparian managers in the grey literature (Vivier et al., 2018, Fédération des Conservatoires d'espaces naturels, 2018). However, it is difficult for managers to know whether and which remote sensing methods are relevant to a particular situation (Dufour et al., 2012).

The use of remote sensing to study riparian vegetation raises specific challenges. These challenges are linked to the vegetation's relative structural complexity and spatial organization (Naiman and Décamps, 1997), or to the difficulty to extract specific features or processes related to riparian vegetation functions (e.g. surface roughness by Straatsma and Baptist (2008), shading of streams by Loicq et al., 2018). In a recent literature review, remote sensing emerged as a particularly dynamic subject in riparian studies (Dufour et al., 2019). Remote sensing of riparian vegetation was mentioned in several reviews addressing the remote sensing of rivers (Muller et al., 1993; Goetz, 2006, Tomsett and Leyland, 2019, Piégay et al., 2020). Specific aspects were also reviewed such as 
the mapping of roughness coefficients with remote sensing (Forzieri et al., 2012) or the use of satellite images to map riparian vegetation in New Zealand (Ashraf et al., 2010). Dufour et al. (2012) and Dufour et al. (2013) summarized and discussed several examples of remote sensing applications to map riparian vegetation. However, none of the aforementioned articles comprehensively reviewed the use of remote sensing to map riparian vegetation across regions, scales and researcher's interests. Indeed, the latter are fragmented among several fields of knowledge (e.g. ecology, geomorphology or hydraulics) (Dufour et al., 2019).

The aims of this article are 1) to provide a comprehensive overview of the relevance of remote sensing to support the study of riparian vegetation and 2) to discuss how remote sensing approaches can be valued as operational tools for managing riparian vegetation. To these ends, we first systematically review the different types of data used to study major features, functions and processes related to riparian vegetation across scales (section 3). The second part of the article (section 4) is based on expert judgment. We provide concrete examples where remote sensing is used in management contexts, in order to identify the challenges of conveying remote sensing tools from scientists to managers.

\section{Materials and methods}

Our approach was structured as following: we first selected relevant articles in the Scopus database. Second, relevant information was extracted for each article, and summarized into graphs. Our results were discussed in terms of trends and perspectives for research, and in terms of operationality and transferability to riparian managers. The Figure 1 synthesizes our approach. Major steps are further detailed in the following sections. 


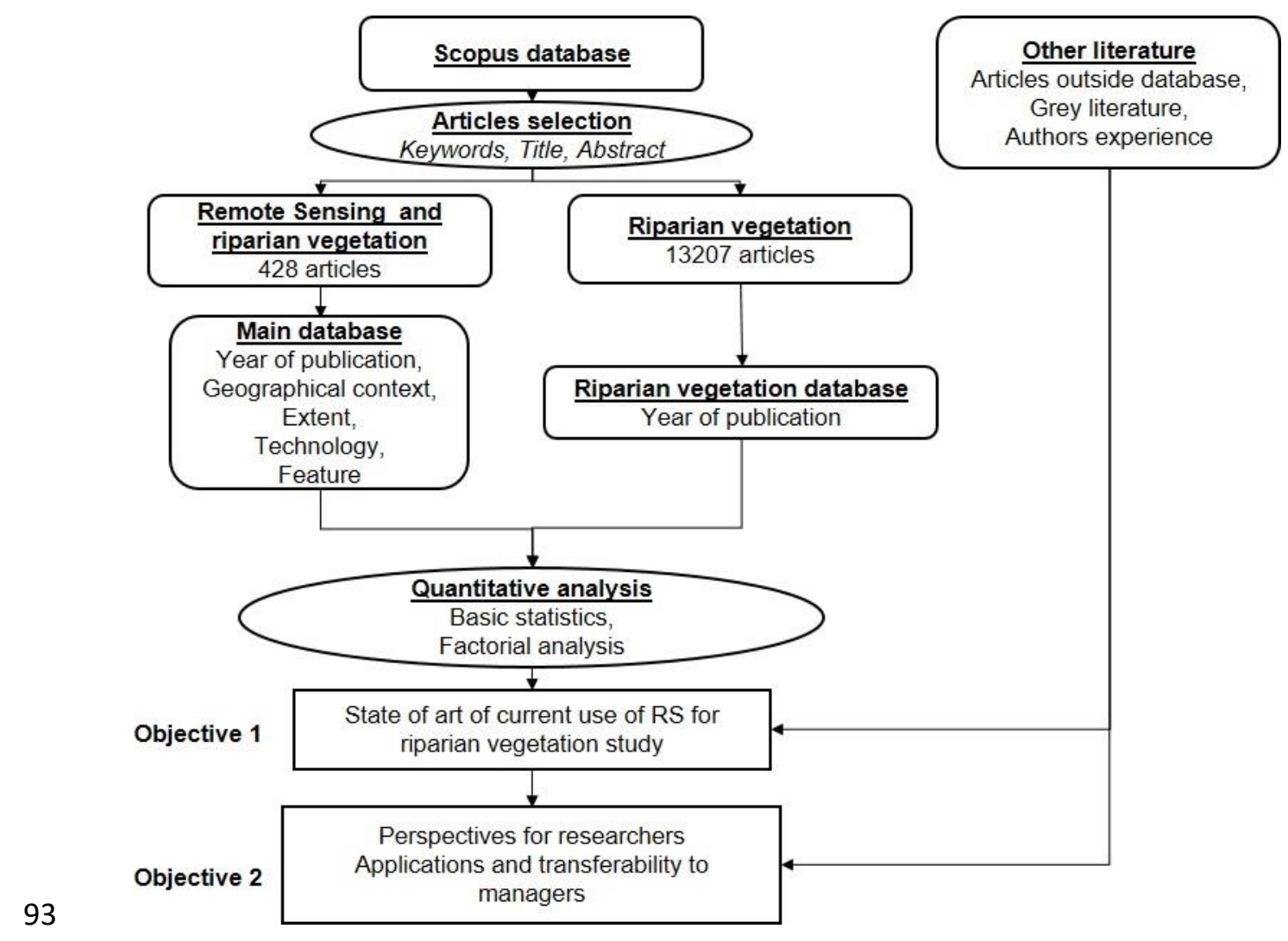

Figure 1. General workflow for the reviewing process

\subsection{Database collection}

Relevant articles were selected from the Scopus database (www.scopus.com) for the period 1980 April 2018, when the database was queried. We searched the title, abstract and the keywords for words related both to riparian vegetation and to remote sensing technologies. More precisely, we used the request described in the Figure 2.

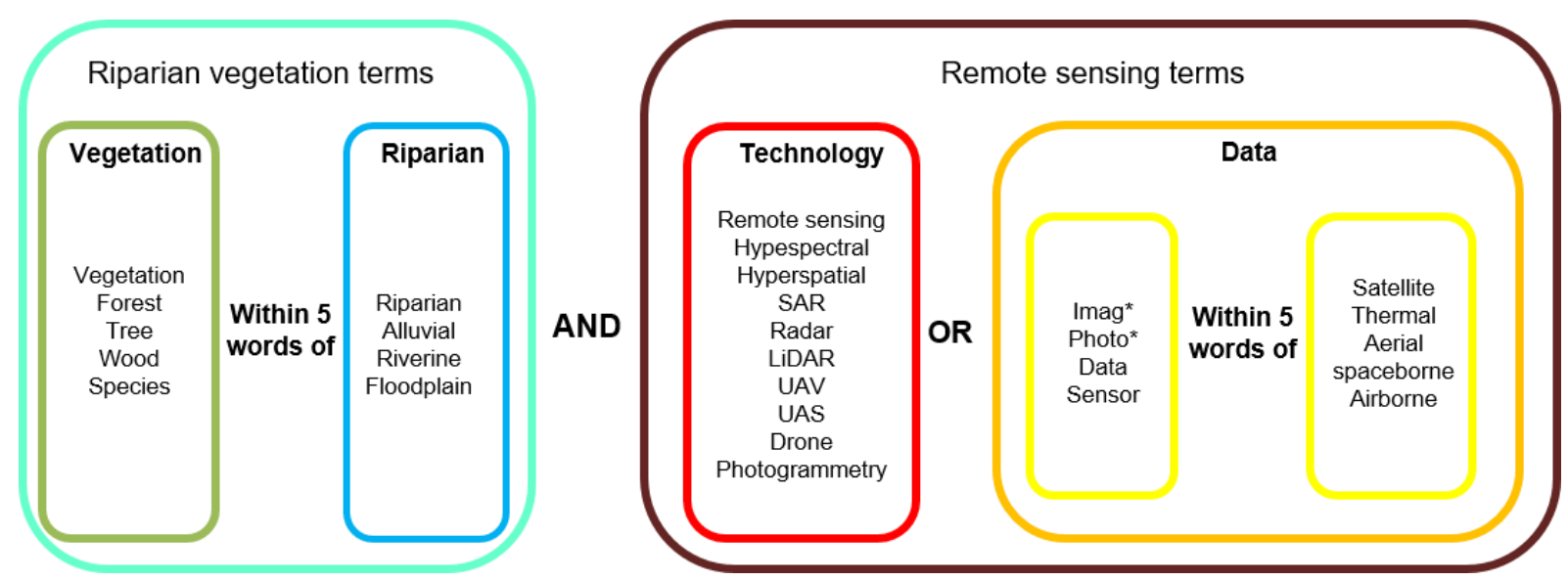

Figure 2. Keywords used for database collection 
Our choice of keywords excluded articles that mentioned riparian zones, but not specifically riparian vegetation. While some of these articles could have been relevant for this review, including keywords related to riparian zones would have resulted in unmanageable noise.

This request yielded 791 articles. We first filtered out irrelevant articles based on their title (672 articles kept). Then, we sorted through the remaining articles based on their abstracts (428 articles kept). During these two filtering steps, we removed mainly articles in which riparian vegetation was not an essential part of the study. For example, we removed geomorphological articles in which riparian vegetation was mentioned in the abstract but was not actually studied. Articles that used GIS but no remote sensing data were also removed (e.g. those using cadastral archives).

We also built a second database using only keywords related to riparian vegetation, excluding those related to remote sensing. This second database was solely used to estimate the proportion of remote sensing studies among riparian vegetation studies, and was not analyzed using the analysis grid described in the following section.

\subsection{Analysis grid}

We searched for features that characterized the articles collected to perform quantitative analysis and statistics. We built our analysis grid (Table 1) around five groups of variables: "general information", "remote sensing technology", "study extent", "type of indicator" and "multitemporality". In this paragraph, when not obvious, we highlight in bold the codes (used in figures) associated with the variables. "General information" included variables such as the publication year and location of study area. "Remote sensing technology" described the type of remote sensing data used. To simplify interpretation, we recorded this information as common combinations of sensors and vectors. We distinguished the following: airplane with a RGB/GS (red-green-blue or panchromatic), digital or analog sensor (Plane_RGB); airplane with a multispectral or hyperspectral sensor (Plane_MSHS); UAV with any sensor (UAV); any vector with a LiDAR sensor (LiDAR); any vector with a RADAR sensor (RADAR) and satellite with a multispectral or hyperspectral sensor. This 
last variable was coded according to image resolution: medium (>10 m, Satlow) or high ( $\leq 10 \mathrm{~m}$,

128 Sathi). "Study extent" described the extent of the study area as the length of studied river or area of the study area. These two variables were recorded in categories and then summarized into a single category to simplify interpretation: study extent. "Type of indicator" described the type of features extracted with remote sensing data to describe riparian vegetation. Delineation of riparian vegetation among other land cover types (DLC) is the first feature extracted for managing riparian vegetation. Species composition is a major feature of riparian plant formations. It is related to habitat provision, bank stabilization and flood regulation functions; for example, willow is a pioneer species that helps to stabilize banks (Hupp, 1992). We distinguished studies that differentiate groups of species (Communities) and studies that differentiate species (SP). We also distinguished studies in which the target species were invasive (SP_invasive), since riparian zones are particularly prone to invasions (Richardson et al., 2007). We distinguished studies in which the target communities were succession stages, since riparian systems are pulsed systems in which succession is regularly reinitiated, leading to a mosaic of succession stages (Kalliola and Puhakka, 1988). The structure of riparian vegetation is related to many ecological functions. We recorded general descriptors of vegetation structure such as vegetation height, density, biomass and landscape structure. We also recorded studies interested in hydraulic properties of vegetation (Roughness), since riparian vegetation has tremendous effects on the hydraulic regime of rivers, especially by slowing river flow (Curran and Hession, 2013). Riparian shade (or overhang) influences fish habitats and is a major factor regulating stream temperature (Poole and Berman, 2001). Large woody debris (LWD) has many effects on provision of aquatic habitats, river morphology and flood risk prevention (Wohl, 2017). Features related to physiological processes, including phenology and health statuts (e.g. tree dieback), are a major concern for managers (Cunningham et al., 2018). Riparian evapotranspiration

150 has often been studied in arid or semi-arid systems because it has a major effect on providing water 151 for human use (Dahm et al., 2002). "Multi-temporality" included only one variable (Diachronic), which corresponded to a special type of study - diachronic analysis - that uses a temporal series of 


\begin{tabular}{|c|c|c|c|}
\hline Group of variables & Variable & Values & Description \\
\hline \multirow[t]{4}{*}{ General information } & Year & & Publication year \\
\hline & $\mathrm{X} 1$ & & Longitude of the study area \\
\hline & $\mathrm{Y1}$ & & Latitude of the study area \\
\hline & Biome & & $\begin{array}{l}\text { World Wildlife Fund Biome of the study } \\
\text { area (extracted from the geographical } \\
\text { coordinates of the study area) }\end{array}$ \\
\hline \multirow[t]{7}{*}{ Type of remote sensing } & Plane_RGB & $0 / 1$ & $\begin{array}{l}\text { Use of black and white or true-color aerial } \\
\text { images (except images acquired from UAVs) }\end{array}$ \\
\hline & Plane_MSHS & $0 / 1$ & $\begin{array}{l}\text { Use of aerial images with } 4 \text { or more spectral } \\
\text { bands (except those from UAVs) }\end{array}$ \\
\hline & Satlow & $0 / 1$ & $\begin{array}{l}\text { Use of satellite images with resolution }>10 \\
\mathrm{~m}\end{array}$ \\
\hline & Sathi & $0 / 1$ & $\begin{array}{l}\text { Use of satellite images with resolution } \leq 10 \\
\mathrm{~m}\end{array}$ \\
\hline & UAV & $0 / 1$ & Use of images acquired from UAVs \\
\hline & LiDAR & $0 / 1$ & Use of LiDAR data \\
\hline & RADAR & $0 / 1$ & Use of RADAR data \\
\hline \multirow[t]{3}{*}{ Extent of the study area } & Length & 1 to 5 & $\begin{array}{l}\text { Length of the river studied (for studies at } \\
\text { the scale of the minor bed or floodplain) }\end{array}$ \\
\hline & Area & 1 to 5 & $\begin{array}{l}\text { Area of the study area (for studies at the } \\
\text { watershed scale) }\end{array}$ \\
\hline & Study extent & 1 to 5 & $\begin{array}{l}\text { Combination of Length and Area: } \\
\text { - } \quad \text { Local: Length }<10 \mathrm{~km}\end{array}$ \\
\hline
\end{tabular}




\begin{tabular}{|c|c|c|c|c|}
\hline & & & & 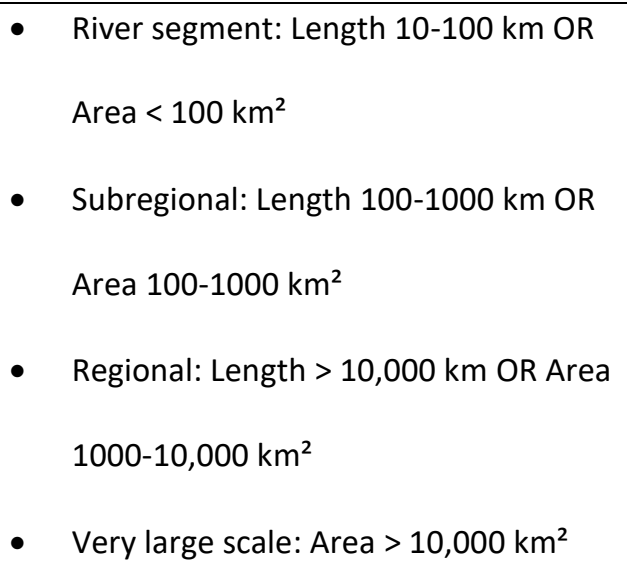 \\
\hline \multirow[t]{15}{*}{$\begin{array}{l}\text { Type of } \\
\text { indicator }\end{array}$} & Delimitation & DLC & $0 / 1$ & $\begin{array}{l}\text { Mapping of riparian vegetation (including } \\
\text { land cover studies) }\end{array}$ \\
\hline & \multirow[t]{4}{*}{$\begin{array}{l}\text { Species } \\
\text { composition }\end{array}$} & Communities & $0 / 1$ & $\begin{array}{l}\text { Mapping of several distinct riparian plant } \\
\text { communities }\end{array}$ \\
\hline & & Succession stages & $0 / 1$ & Mapping of several succession stages \\
\hline & & SP & $0 / 1$ & $\begin{array}{l}\text { Mapping of riparian vegetation at the } \\
\text { species level }\end{array}$ \\
\hline & & SP_invasives & $0 / 1$ & Mapping of invasive species \\
\hline & \multirow{7}{*}{$\begin{array}{l}\text { Vegetation } \\
\text { structure }\end{array}$} & Height & $0 / 1$ & Mapping of vegetation height \\
\hline & & Landscape & $0 / 1$ & $\begin{array}{l}\text { Calculation of landscape metrics (e.g. } \\
\text { continuity) }\end{array}$ \\
\hline & & Density & $0 / 1$ & Mapping of vegetation density \\
\hline & & Shade & $0 / 1$ & Mapping of shade cast by vegetation \\
\hline & & Biomass & $0 / 1$ & Mapping of biomass \\
\hline & & LWD & $0 / 1$ & Large woody debris (wood in rivers) \\
\hline & & Roughness & $0 / 1$ & Mapping of vegetation hydraulic properties \\
\hline & \multirow{3}{*}{$\begin{array}{l}\text { Physiological } \\
\text { processes }\end{array}$} & Evapotranspiration & $0 / 1$ & Estimate of vegetation evapotranspiration \\
\hline & & Health status & $0 / 1$ & $\begin{array}{l}\text { Mapping of vegetation health status (e.g. } \\
\text { tree dieback, defoliation) }\end{array}$ \\
\hline & & Phenology & $0 / 1$ & Mapping of vegetation phenology \\
\hline \multicolumn{2}{|c|}{ Multi-temporality } & Diachronic & $0 / 1$ & Diachronic analysis \\
\hline
\end{tabular}




\subsection{Statistical analysis}

157 We computed the annual number of published studies using remote sensing of riparian vegetation. We also computed for each year the proportion of studies that used remote sensing among all riparian vegetation studies. To do so, we compared the number of articles in the database related to remote sensing and riparian vegetation with the number of articles in the database related to riparian vegetation in general.

The data collected with the analysis grid were summarized and plotted. We computed the number of articles for each WWF biome, the use of different remote sensing technologies through time. We then compared the use of different technologies according to the scale of observation, the indicator extracted and the multi-temporal character of studies.

Finally, we performed a multiple correspondence analysis in order to highlight relationships between the type of data and the type of feature extracted. We used the package FactoMineR of R software. All variables were recorded as categorical variables. Variables related to study extent and multitemporality were added as supplementary variables.

\subsection{Interpretation of results}

171 Results were discussed in two phases. First (section 3), we use our quantitative review of the

172 literature to establish the state of the art and main perspectives in the use of remote sensing to map riparian vegetation. Second (section 4), we discuss how remote sensing can be used in real management contexts. We first discuss the added value of remote sensing in such contexts using concrete examples from the grey literature and personal experience. Then, we use these examples to discuss the challenges that must be overcome in order to promote the use of remote sensing by

177 riparian managers. Therefore, while the section 3 of this article is based on a rigorous review of the 178 scientific literature, the section 4 of this article is rather based on expert judgment. 


\section{Results and discussion of the systematic review}

\subsection{Location of the studies}

Most studies in the 428 selected layed in the Northern Hemisphere (79\%), especially in North America (40\% of studies) and Europe (20\% of studies) (Figure 3). South America, Oceania, Asia (mostly Japan) and Africa represented respectively $9 \%, 9 \%, 11 \%$ and $5 \%$ of studies. Most represented (14\%), and deserts and xeric bushes (13\%). Mediterranean biomes (10\%) and temperate open biomes (8\%) were also well represented. Well-represented biomes generally corresponded to those in developed countries. Conversely, boreal forests and tundra were least represented $k 1 \%$ of studies), though they cover a large area globally (> $10 \%$ of emerged land area). In addition, despite emerged land area), few studies focused on them.

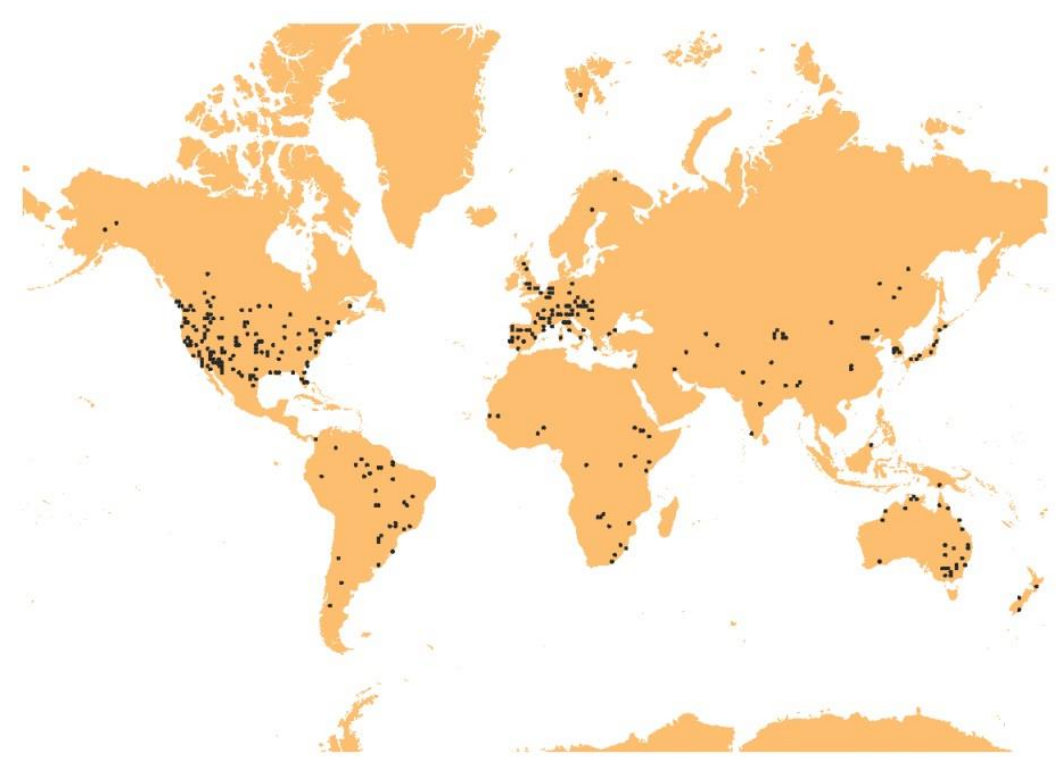


193

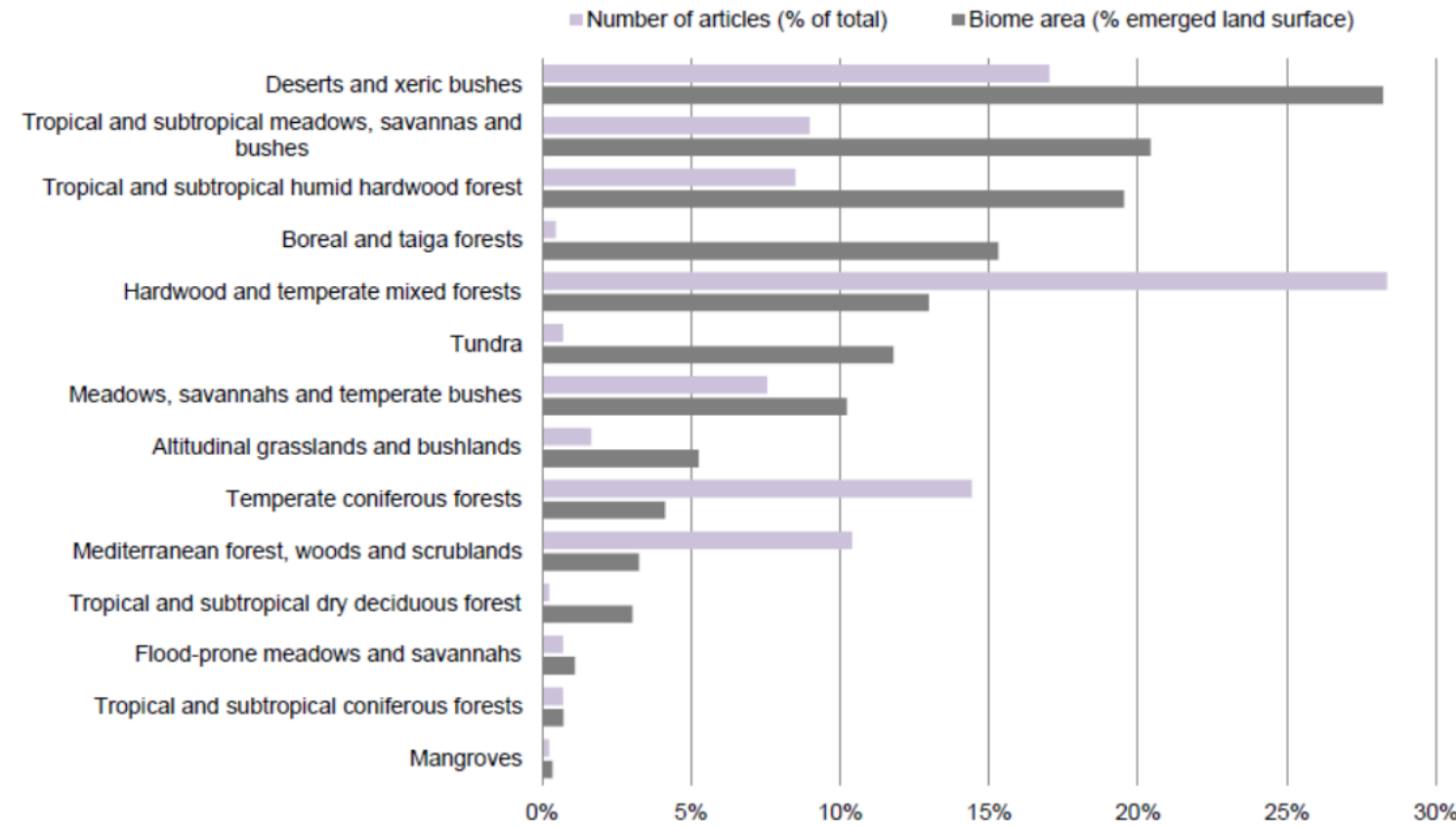

Figure 4. Locations of studies reviewed, by World Wildlife Fund biome

This result highlights the lack of knowledge and studies about tropical and boreal riparian forests, perhaps due to the location of laboratories, which are often located in developed countries and temperate climates. Our results are similar to those of Dufour et al. (2019) for all riparian vegetation studies and those of Bendix and Stella (2013) for studies of vegetation/hydromorphology relationships.

However, we suggest that the increasing quality of remote sensing data has great potential for research in understudied areas and at the global scale. One condition is that these data must be available to their potential users. Open or free remotely sensed data, such as Landsat, MODIS or, more recently, Sentinel images, allow researchers to overcome the issue of the prohibitive cost of data acquisition. This is particularly true for researchers in developing countries for data that are produced in wealthier countries (Sá and Grieco, 2016). However, to broaden the user base, it is also necessary to facilitate access to these data (Turner et al., 2015). Access can be facilitated by providing higher-level (e.g. atmospherically corrected) or derived products, such as global land cover maps (Gong et al., 2013), global floodplain models (Nardi et al., 2019) and maps of riparian zones 
(Weissteiner et al., 2016, at the European scale). Access can also be made easier by developing an open, free or user-friendly environment to find, visualize and process data (Turner et al., 2015). sensing to study riparian vegetation

Most of the 428 studies (89\%) that used remote sensing to study riparian vegetation from 1980-2018 were published after 2000 (Figure 5A), when the number of studies began to increase greatly. Before 1990, few studies used remote sensing to study riparian vegetation. The percentage of studies using remote sensing among studies studying riparian vegetation increased in the 2000s (Figure 5B). Each year after $2000,2-6 \%$ of all studies of riparian vegetation used remote sensing. Thus, even recently, relatively few studies use remote sensing data to study riparian vegetation, and field-based approaches dominate riparian vegetation studies despite the development of remote sensing and modeling approaches. This could be due to three main reasons. First, field-based approaches have traditionally been used and are straightforward. Some aspects of riparian vegetation, such as biogeochemical functioning and soil properties, cannot realistically be studied with remote sensing (Dufour et al., 2012). Second, the spatial structure of riparian vegetation makes it difficult to study using remote sensing. Its complexity (Naiman et al., 2005) and narrow shape is difficult to observe with low resolution satellite images (Johansen et al., 2010). Additionally, the linear shape of riparian corridors requires acquiring images over large areas (to cover sufficient corridor length), only to focus on small areas (near the river, rather than other land cover classes). For example, Weissteiner et al. (2016) estimated that Europe's riparian area represented ca. 1\% of its total continental area. Third, we removed duplicate and irrelevant articles from our database, but did not do so when identifying all articles describing studies of riparian vegetation in general, which may have led us to underestimate the percentage of all riparian studies that used remote sensing. 

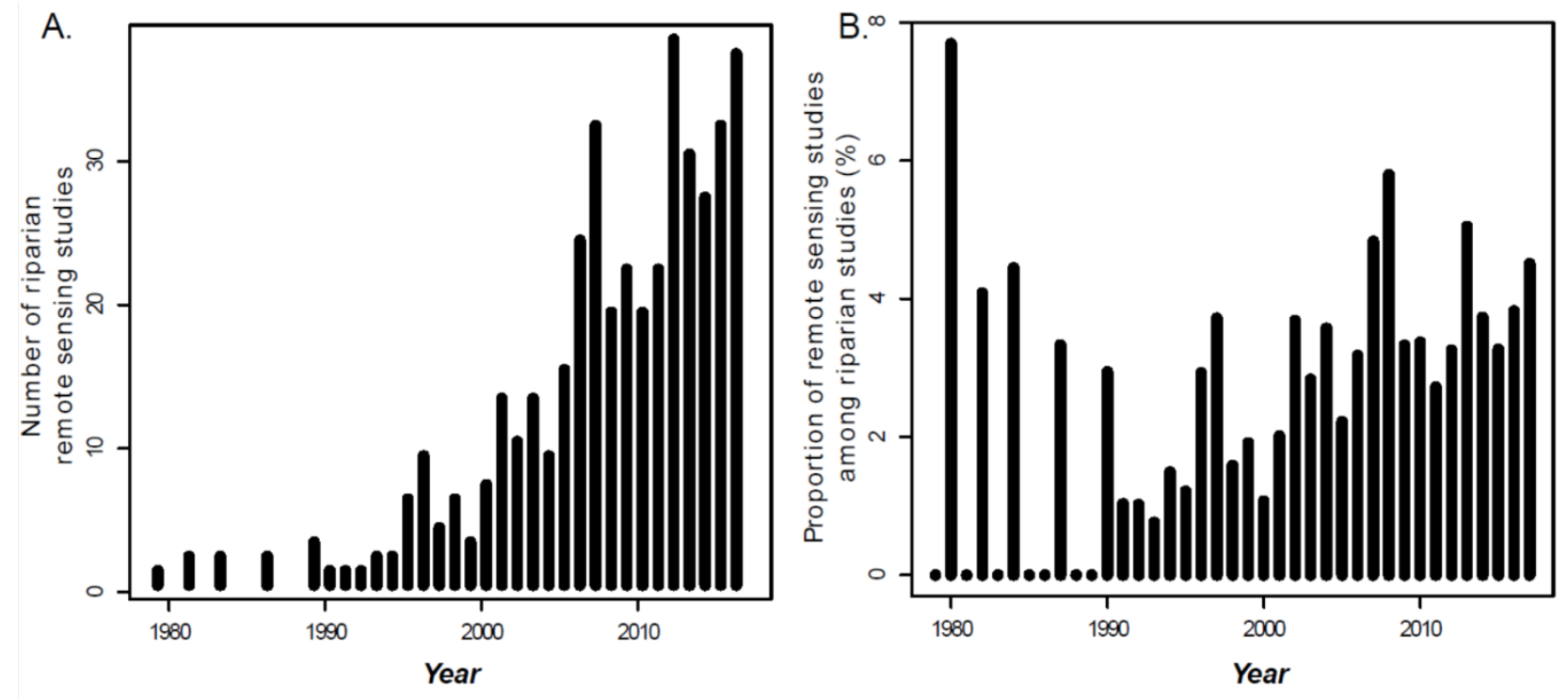

Figure 5. A: Number of studies from 1980-2018 that used remote sensing to study riparian vegetation. B: Percentage of

studies from 1980-2018 that used remote sensing, out of all studies concerning riparian vegetation (see section 2.3).

\subsection{Changes in remote sensing data over time}

The remote sensing data used most were aerial RGB/GS images (44\% overall) and medium-resolution

satellite images (> $10 \mathrm{~m}$ resolution, and $\leq 50 \mathrm{~m}$ for most studies) (Figure 6). Aerial multispectral

images appeared in the 1990s and peaked during the 2000s. The use of high resolution satellite data

( $\leq 10 \mathrm{~m}$ such as IKONOS, SPOT 5 and WorldView) started in the late 1990s and reached a plateau

around 2010. The use of LiDAR data consistently increased during the 2000 s, accounting for $20 \%$ of 


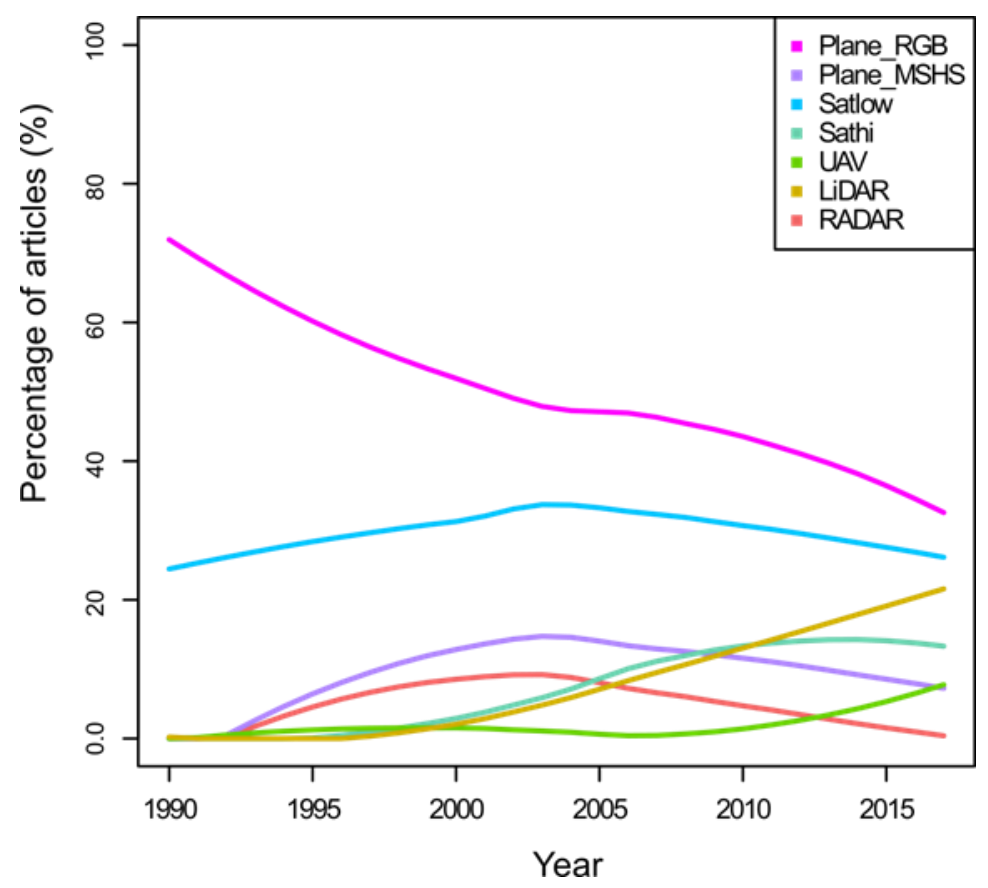

Figure 6. Percentage of studies that used a given technology per year. The curve was smoothed using a loess regression.

The popularity of RGB/GS aerial and low resolution satellite images can be explained by their low cost and wide availability, including as time series. Other data have been used as they became available (e.g. LiDAR and high resolution satellite images in the 2000s, UAVs in the 2010). The relative decrease in the use of multispectral aerial images could be due to their replacement by high resolution satellite images. Finally, the low percentage in the use of RADAR data could be due to the relative difficulty of interpretation of such data, especially as water surfaces can modify RADAR signals. Most studies in our database that used RADAR data focused on the interaction between water and riparian vegetation, mapping flooding events or roughness coefficients (Townsend, 2002).

255 The early decrease in the use of RADAR data coincides with the increase in the use of LiDAR data, 256 which also provide structural information.

\subsection{Which technology for which study scale?}

258 There was a strong relationship between the scale of the study (local to very large scale) and the type of remote sensing data used (Figure 7). In general, aerial images were used more at relatively local scales (i.e. local and river segment), while medium-resolution satellite images were used more at larger scales (i.e. regional or very large scale). There is often a tradeoff between resolution and 

$250 \mathrm{~m}$ for MODIS) but can cover large areas.

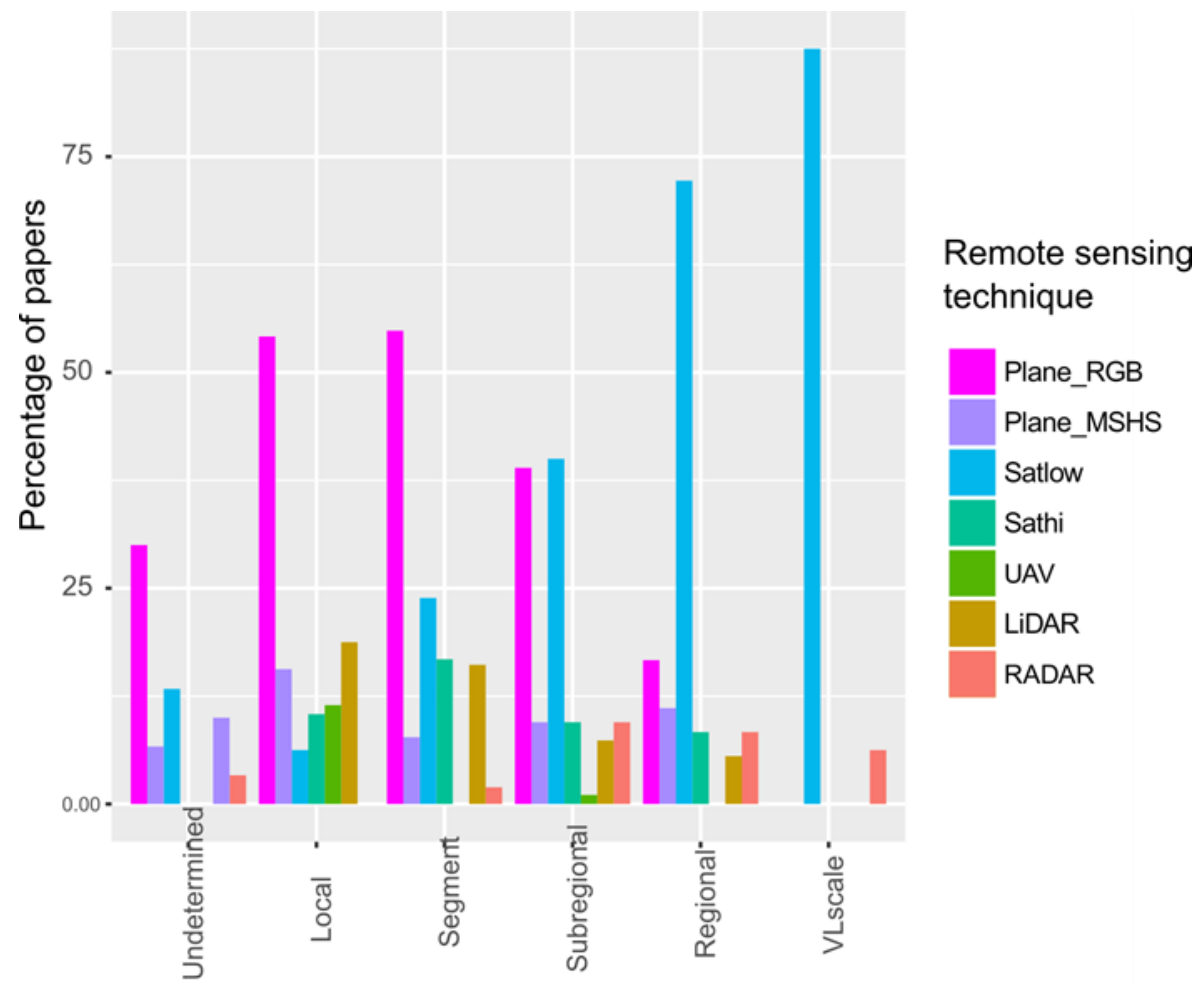

Extent

Figure 7. Percentage of studies that used a given remote sensing technology, by spatial extent of the study

\subsubsection{Use of UAVs at the local scale}

At the local scale $(<10 \mathrm{~km}$ long), $86 \%$ of studies were based on airborne remote sensing (of which $79 \%$ used airplanes and $11 \%$ used UAVs). This scale of study lies within the range of action of relatively inexpensive UAVs that can carry RGB and multispectral cameras. While most UAVs were used at the local scale, the low percentage of local scale studies that used UAVs was surprising. This can be explained by the recent availability of these platforms: of studies published in the 2010 s, $20 \%$ of those at the local scale used UAVs. UAVs are considered more versatile than planes, and a growing number of "ready-to-fly" platforms allow end-users to perform their own acquisitions (Anderson and 275 Gaston, 2013). Moreover, UAV imagery provides very high spatial resolution imagery (up to centimetric), which is ideal for operator photointerpretation, which is frequently used at this scale. 
However, most developed countries have established regulations that restrict the potential and spread of UAV technology (Stöcker et al., 2017).

\subsubsection{Use of airplanes and satellites at the segment and subregional scales}

Both airborne and spaceborne sensors were used the segment $(10-100 \mathrm{~km})$ and subregional scales (100-1000 km). RGB/GS aerial images were used in $55 \%$ and $39 \%$ of studies at respectively the riversegment and subregional scale (Figure 7). Most researchers photointerpret these images to describe riparian vegetation features. This method is long-standing, but remains a relevant and effective approach to map riparian vegetation over small watersheds or along dozens (more rarely hundreds) of km of rivers (Jansen and Backx, 1998; Matsuura and Suzuki, 2013; Carli and Bayley, 2015; González del Tánago et al., 2015; Solins et al., 2018). However, photointerpretation of hundreds of $\mathrm{km}$ of river can become tedious. In this case, one would use more automated approaches, such as object-based approaches, which can decrease the time required for photointerpretation (Belletti et al., 2015).

The effectiveness of automated techniques is strongly correlated with the homogeneity of spectral signatures within a single feature class (Cushnie, 1987). Homogeneity in spectral signatures requires homogeneous atmospheric and illumination conditions within the dataset. To this end, airplanes equipped with multispectral cameras can be used over long river segments in a short period to avoid variations in weather and illumination conditions (Forzieri et al., 2013; Bucha and Slávik, 2013). However, this approach remains challenging for large river networks, which decreases the possibilty of automation at these scales (Dauwalter et al., 2015).

In this context, the wider swath of satellite imagery would be an advantage. High-resolution satellite images were often used to map vegetation automatically (16\% and $9 \%$ of studies at respectively the river-segment and subregional scale) (Figure 7). For example, Strasser and Lang (2015), Riedler et al. (2015) and Doody et al. (2014) used WorldView-2 data to map riparian vegetation along a few dozen km. Tormos et al. (2011) and Macfarlane et al. (2017) used SPOT images and GeoEye-1 images to map vegetation along corridors respectively 60 and $90 \mathrm{~km}$ long. However, it may be difficult to 
acquire high-quality datasets for larger areas, for which several high-resolution satellite images must be combined (Goetz, 2002; Johansen et al., 2010b; Zogaris et al., 2015).

The percentage of studies based on LiDAR surveys decreased with scale: $19 \%, 16 \%, 7 \%$ and $6 \%$ of studies at respectively the local, river-segment, subregional and regional scale (Figure 7). However, some authors were able to use LiDAR data to monitor narrow riparian corridors over large areas (Johansen et al., 2010; Michez et al., 2017). One advantage of tri-dimensional LiDAR data is that they are less subject to changing atmospheric and lightning conditions during the survey than spectral data. Moreover, LiDAR coverage is becoming more frequent at the regional/national scale (Parent et al., 2015; Wasser et al., 2015; Shendryk et al., 2016; Tompalski et al., 2017). When an initial nationwide LiDAR survey is performed, digital aerial photogrammetry (DAP) can be used to further update LiDAR canopy height models (CHMs). DAP CHMs can be produced from aerial images acquired on a regular basis by national or regional mapping agencies in several countries and can potentially provide vegetation height data at low additional cost (Michez et al., 2017).

\subsubsection{Large scale: satellite images}

The use of satellite images with medium to coarse resolution (>10 m) increased as the extent increased. For studies at the regional or very large scale, satellite images were used in respectively $72 \%$ and $82 \%$ of cases (Figure 7). Coarse-resolution images ( $>100 \mathrm{~m}$ ) were not used to study riparian vegetation, which often appears as linear or fragmented features (Gergel et al., 2007). Mediumresolution images such as Landsat TM, ETM+ or OLI images are preferred. The use of these data to map riparian vegetation cover has yielded satisfying results in wide riparian corridors (Lattin et al., 2004, Yousefi et al., 2018). However, their resolution often becomes limiting in the case of narrow riparian corridors or small vegetation units that are a few Landsat pixels wide (Congalton et al., 2002, Henshaw et al., 2013). Although aerial images (multispectral, RGB and panchromatic) were used in $25 \%$ of studies at the regional scale, they were always used with medium-resolution satellite images (Fullerton et al., 2006; Groeneveld and Watson, 2008; Claggett et al., 2010). High-resolution satellite 
327 images, which were used in $8 \%$ of studies at the regional scale, were used mostly with pansharpening

328 methods to enhance lower resolution satellite images (Seddon et al., 2007; Staben and Evans, 2008;

329 Scott et al., 2009).

\subsection{Which technology for which riparian feature?}

331 The features of interest extracted from remote sensing data to describe riparian vegetation were 332 strongly related to the type of remote sensing data (Figure 8). Four major trends emerged. First, the 333 study of physiological processes (e.g. phenology, evapotranspiration and, to a lesser extent, health status) was strongly associated with the use of medium-resolution satellite images and large study extents. Second, the study of features or processes related to vegetation structure (shade, roughness, height) was strongly associated with the use of LiDAR data. Third, the study of features related to species composition was associated with the use of high-resolution multispectral images

338 (acquired from satellites, planes or UAVs) or RGB/GS aerial images (especially for successional stages)

339 and with small study extents. Fourth, the delineation of riparian vegetation was weakly associated with the use of RGB/GS aerial images or medium-resolution satellite images. These four trends are discussed in the following four sections. 


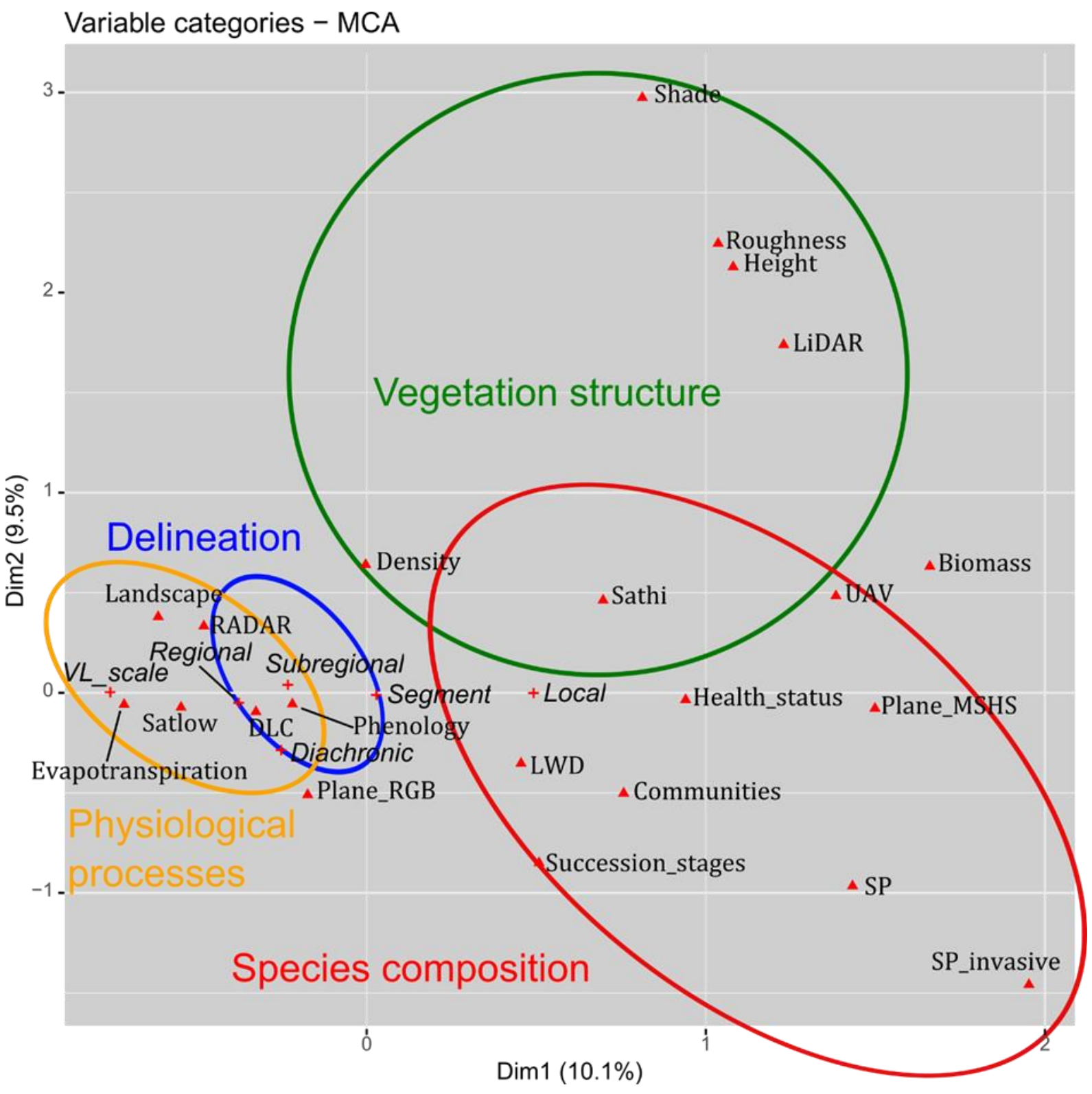

Figure 8. Results of the multiple correspondence analysis (see section 2.3. for the methods). Supplementary variables (i.e.

variables related to study extent and multi-temporality) are represented as crosses with text in italics. The first two axes explain $19.6 \%$ of total variance. Ellipses were drawn arbitrarily to simplify interpretation. See Table 1 for code definitions.

\subsubsection{Delineation of riparian vegetation}

How riparian vegetation is delineated depends on how it is defined (Verry et al., 2004). In general, riparian vegetation is defined based on its specific characteristics (e.g. spectral signature, texture) and on contextual information (e.g. topographic position, proximity to a river) (Weissteiner et al., 2016). Photointerpretation of RGB/GS aerial images is a traditional approach in which the operator uses both types of information (Morgan et al., 2010). It was used in 53\% of studies that delineated 
riparian vegetation (Figure 9). Multispectral images (airborne or spaceborne, accounting for $45 \%$ of studies) are often used to delineate riparian vegetation in an automated way (Alaibakhsh et al., 2017; Johansen et al., 2010b; Bertoldi et al., 2011). Contextual information can be provided by ancillary data (e.g. hydrographic network, as in Claggett et al. (2010) or Yang (2007)), a LiDAR digital terrain model (DTM) (Arroyo et al., 2010; Wagner-Lücker et al., 2013), or a Shuttle RADAR Topography Mission DTM (Maillard and Alencar-Silva, 2013; Weissteiner et al., 2016). Congalton et al. (2002) indicate that medium-resolution satellite data (used in $29 \%$ of studies) are not adapted for delineating narrow riparian corridors because the corridors do not contain enough pixels (see section 3.4.3).

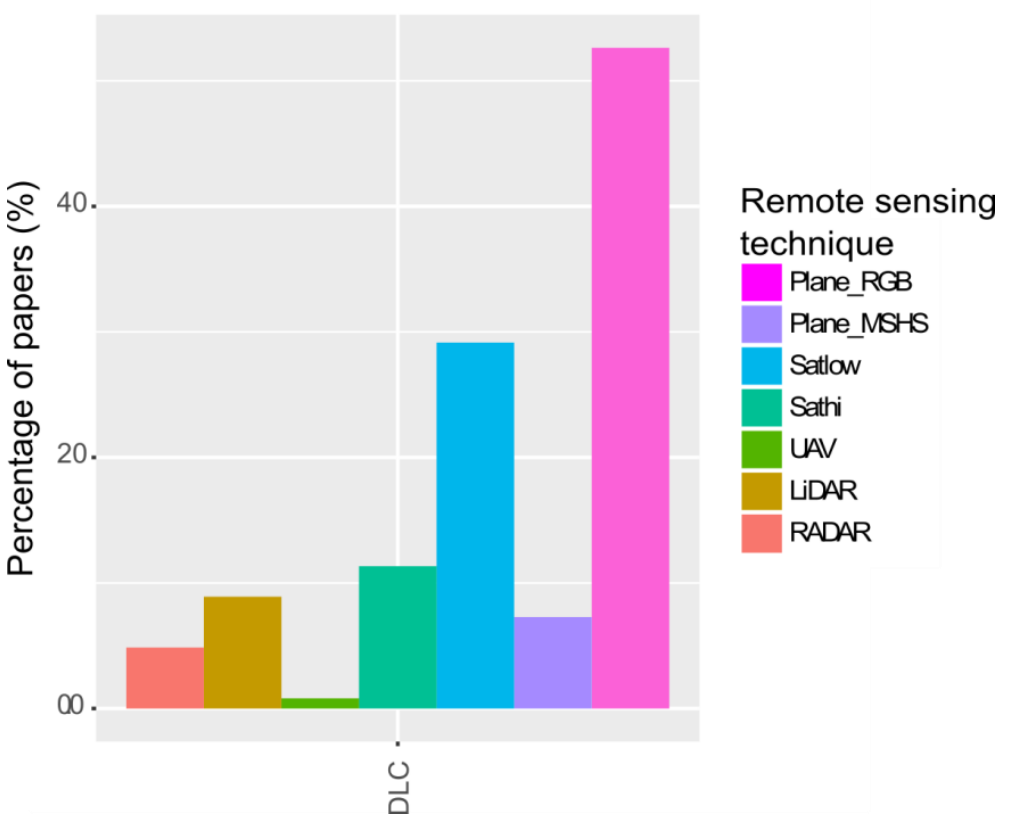

Figure 9. Percentage of studies that used given remote sensing data to delineate riparian vegetation (i.e. distinguish riparian vegetation from other land-cover types)

\subsubsection{Species composition}

Species composition is a recurrent subject that was studied in $42 \%$ of studies. Photointerpretation of RGB/GS aerial images concerned $51 \%, 47 \%$ and $45 \%$ of studies that differentiated respectively communities, species, and invasive species (Figure 7). This approach is widely used to describe successional stages or changes in their distribution ( $86 \%$ of such studies). Indeed, RGB/GS aerial images have been available since before the 1950s (González et al., 2010; Rood et al., 2010; Varga et 
al., 2013; Wan et al., 2015). However, manual interpretation of images is time-consuming, and the

371 discriminating power of RGB/GS aerial images is limited by their low spectral range (Narumalani et al., 2009; Fernandes et al., 2014). Medium-resolution satellite images were used in $21 \%$ of studies that differentiated communities. These images were used mainly when vegetation patches were larger than the image resolution (Vande Kamp et al., 2013; Hamandawana and Chanda, 2013; Sridhar et al., 2010; Groeneveld and Watson, 2008; Townsend and Walsh, 2001), although spectral unmixing can, to some extent, resolve this issue (Gong et al., 2015; Wang et al., 2013).

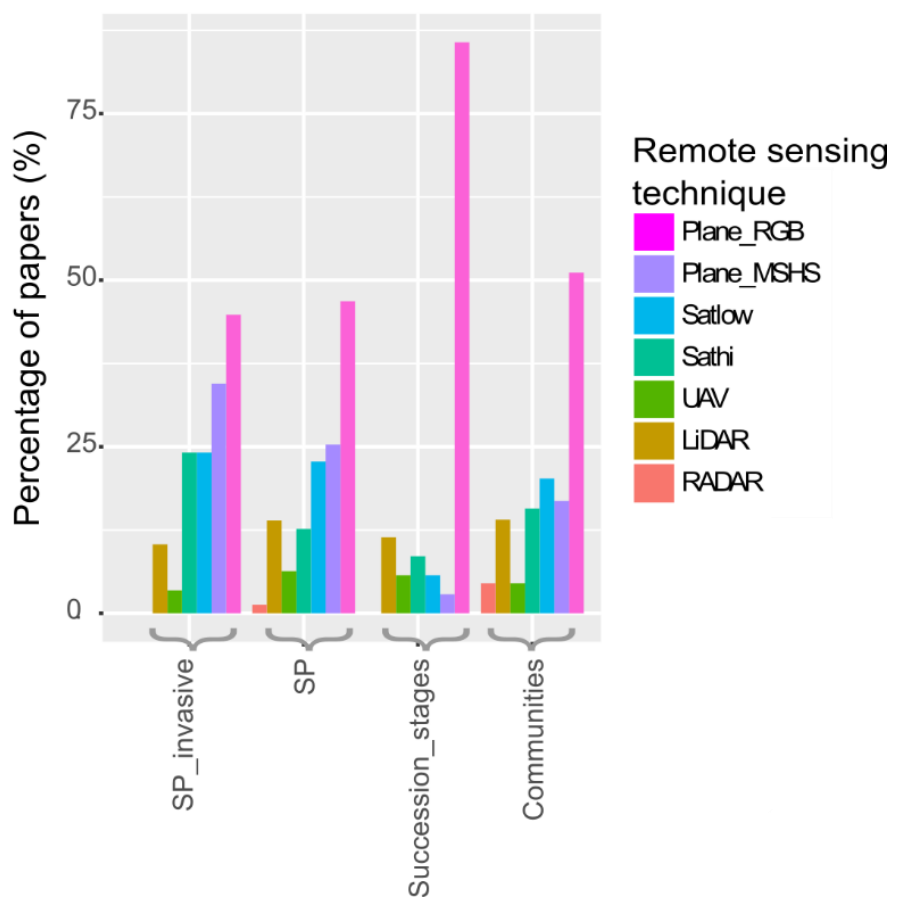

Figure 10. Percentage of studies that used given remote sensing data to map indicators related to species composition.

The most promising approaches to address this issue are based on high-resolution, aerial or spaceborne, multispectral or hyperspectral images. These images were used in $30 \%, 33 \%$ and $45 \%$ of studies that differentiated respectively communities, species and invasive species (Figure 10). The accuracy of a particular project depends on the context, objectives, available data and methods used to evaluate it. Therefore, we present recent studies that mapped species in the Table 2. In general, a large number of narrow spectral bands increases the ability to distinguish species. However, in mature, species-rich floodplain forests, it remains challenging to obtain classification accuracy that is 
satisfactory for operational use, even when using hyperspectral imagery (Richter et al., 2016). The use of multi-temporal images, which reveal the succession of phenological stages, can sometimes replace the spectral range. For example, Rapinel et al. (2019) used Sentinel-2 time series to classify grassland plant communities in a temperate floodplain using the relationship between inundation, grassland management and vegetation composition. Similarly, Michez et al. (2016b) used UAV time series to distinguish riparian tree species using images acquired during several phenological stages (from spring to fall). It is also possible to acquire images at a single but appropriate date to take advantage of the singular aspect of one species at a particular phenological stage. This approach is especially effective when a single species has to be mapped, such as the invasive species Arundo donax (Fernandes et al., 2013b) or Heracleum mantegazzianum (Michez et al., 2016a). The spatial resolution of images must be sufficiently high to limit the occurrence of mixed pixels that hinder the performance of automated classifications (Belluco et al., 2006; Narumalani et al., 2009). However, small mixture of species remains a source of difficulty, even with a $\mathrm{cm}$ resolution (Michez et al., 399 2016a). LiDAR data, also used to classify species, can supplement multispectral data with vegetation 400 height data (Forzieri et al., 2013). They can also be used to segment trees before classifying them 401 (Dutta et al., 2017). They have also been used as the sole source of data by relating species identity to the structure of the point cloud (Laslier et al., 2019). 


\begin{tabular}{|c|c|c|c|c|}
\hline Reference & Data & Classes & Accuracy & Comment \\
\hline \multicolumn{5}{|c|}{ Mature riparian forests } \\
\hline $\begin{array}{l}\text { Fernandes et } \\
\text { al. (2013a) }\end{array}$ & $\begin{array}{l}\text { RGB-NIR aerial imagery }(0.5 \mathrm{~m} \\
\text { resolution) }\end{array}$ & $\begin{array}{l}3 \text { types of mature, } \\
\text { temperate/Mediterranean } \\
\text { riparian forests }\end{array}$ & $\begin{array}{l}61 \text { (small) - } \\
78 \% \text { (large } \\
\text { river) }\end{array}$ & \\
\hline $\begin{array}{l}\text { Dunford et } \\
\text { al. (2009) }\end{array}$ & $\begin{array}{l}\text { RGB imagery acquired with UAV } \\
\text { (0.13 m resolution) }\end{array}$ & $\begin{array}{l}4 \text { tree species (Populus, Salix } \\
\text { and } 2 \text { Pinus) in a riparian } \\
\text { Mediterranean forest }\end{array}$ & $\begin{array}{l}91 \% \text { (for an } \\
\text { image) - 71\% } \\
\text { (for a mosaic) }\end{array}$ & \\
\hline $\begin{array}{l}\text { Michez et al. } \\
\text { (2016b) }\end{array}$ & $\begin{array}{l}\text { RGB-NIR imagery acquired with } \\
\text { UAV (0.1 m resolution) }\end{array}$ & $\begin{array}{l}5 \text { tree species in a temperate, } \\
\text { riparian forested/agricultural } \\
\text { landscape }\end{array}$ & $\begin{array}{l}84 \text { (forested) } \\
-80 \% \\
\text { (agricultural) }\end{array}$ & $\begin{array}{l}\text { Multi-temporal } \\
\text { dataset }\end{array}$ \\
\hline $\begin{array}{l}\text { Richter et al. } \\
\text { (2016) }\end{array}$ & $\begin{array}{l}\text { Hyperspectral aerial imagery ( } 367 \\
\text { bands, } 2 \text { m resolution) }\end{array}$ & $\begin{array}{l}10 \text { tree species in a mature } \\
\text { temperate floodplain forest }\end{array}$ & $\begin{array}{l}\text { 74\% (single- } \\
\text { date survey) - } \\
78 \% \text { (two- } \\
\text { date survey) }\end{array}$ & \\
\hline $\begin{array}{l}\text { Dutta et al. } \\
\text { (2017) }\end{array}$ & $\begin{array}{l}\text { Hyperspectral aerial imagery (48 } \\
\text { bands, } 1 \text { m resolution) }\end{array}$ & $\begin{array}{l}4 \text { groups of tree species in a } \\
\text { mature, temperate riparian } \\
\text { forest }\end{array}$ & $86 \%$ & $\begin{array}{l}\text { LiDAR is used to } \\
\text { segment the trees }\end{array}$ \\
\hline $\begin{array}{l}\text { Laslier et al. } \\
\text { (2019) }\end{array}$ & $\begin{array}{l}\text { High density }\left(>45 \text { points } / \mathrm{m}^{2} \text { ) LiDAR }\right. \\
\text { point cloud }\end{array}$ & $\begin{array}{l}8 \text { tree species in a temperate } \\
\text { riparian agricultural/forested } \\
\text { landscape }\end{array}$ & $67 \%$ & \\
\hline \multicolumn{5}{|c|}{ Pionneer/species-poor riparian settings } \\
\hline $\begin{array}{l}\text { Macfarlane } \\
\text { et al. (2017) }\end{array}$ & $\begin{array}{l}\text { Pansharpened GeoEye-1 imagery } \\
\text { (RGB-NIR, } 0.5 \text { m resolution) }\end{array}$ & $\begin{array}{l}\text { Pioneer (Salix, Populus) and } \\
\text { invasive (Tamarix) species in } \\
\text { an arid context }\end{array}$ & $80 \%$ & \\
\hline $\begin{array}{l}\text { Forzieri et al. } \\
\text { (2013) }\end{array}$ & $\begin{array}{l}\text { RGB-NIR aerial imagery ( } 0.2 \mathrm{~m} \\
\text { resolution); hyperspectral aerial } \\
\text { imagery ( } 102 \text { bands, } 3 \mathrm{~m} \\
\text { resolution) and LiDAR data } \\
\text { (DSM/DTM with } 1 \mathrm{~m} \text { resolution) }\end{array}$ & $\begin{array}{l}\text { Pioneer (Salix, Populus) and } \\
\text { invasive (Arundo donax) } \\
\text { species in a temperate } \\
\text { context }\end{array}$ & $93 \%$ & \\
\hline
\end{tabular}




\begin{tabular}{|c|c|c|c|c|}
\hline \multicolumn{5}{|c|}{ Invasive species } \\
\hline $\begin{array}{l}\text { Narumalani } \\
\text { et al. (2009 }\end{array}$ & $\begin{array}{l}\text { Hyperspectral aerial imagery (62 } \\
\text { bands, } 1.5 \text { m resolution) }\end{array}$ & $\begin{array}{l}\text { Tamarix, Elaeagnus } \\
\text { angustifolia, Cirsium arvense, } \\
\text { Carduus nutans and mixed } \\
\text { classes }\end{array}$ & $74 \%$ & $\begin{array}{l}\text { Mixed classes are not } \\
\text { well classified and } \\
\text { decrease overall } \\
\text { accuracy }\end{array}$ \\
\hline \multirow[t]{2}{*}{$\begin{array}{l}\text { Fernandes et } \\
\text { al. (2014) }\end{array}$} & $\begin{array}{l}\text { RGB-NIR aerial imagery }(0.5 \mathrm{~m} \\
\text { resolution) }\end{array}$ & Arundo donax & $97 \%$ & $\begin{array}{l}\text { Choice of the best } \\
\text { date for aerial survey }\end{array}$ \\
\hline & $\begin{array}{l}\text { WorldView } 2 \text { imagery (8 bands, } 2 \mathrm{~m} \\
\text { resolution) }\end{array}$ & Arundo donax & $95 \%$ & \\
\hline \multirow[t]{2}{*}{$\begin{array}{l}\text { Michez et al. } \\
\text { (2016a) }\end{array}$} & $\begin{array}{l}\text { RGB-NIR imagery acquired with } \\
\text { UAV (0.05-0.1 m resolution) }\end{array}$ & Impatiens glandulifera & $72 \%$ & $\begin{array}{l}\text { Mixture with native } \\
\text { species hinders } \\
\text { accurate classification }\end{array}$ \\
\hline & & $\begin{array}{l}\text { Heracleum mantegazzianum } \\
\text { Fallopia japonica }\end{array}$ & $\begin{array}{l}97 \% \\
68 \%\end{array}$ & \\
\hline $\begin{array}{l}\text { Peerbhay et } \\
\text { al (2016) }\end{array}$ & $\begin{array}{l}\text { WorldView } 2 \text { imagery (8 bands, } 2 \mathrm{~m} \\
\text { resolution) }\end{array}$ & Solanum mauritanum & $68 \%$ & \\
\hline $\begin{array}{l}\text { Miao et al. } \\
\text { (2011) }\end{array}$ & $\begin{array}{l}\text { Hyperspectral aerial imagery (227 } \\
\text { bands, } 1 \text { m resolution) }\end{array}$ & $\begin{array}{l}\text { Prosopis glandulosa and } \\
\text { Tamarix }\end{array}$ & $92 \%$ & \\
\hline $\begin{array}{l}\text { Doody et al. } \\
(2014)\end{array}$ & $\begin{array}{l}\text { WorldView } 2 \text { imagery (8 bands, } 2 \mathrm{~m} \\
\text { resolution) }\end{array}$ & Salix & $93 \%$ & \\
\hline
\end{tabular}

These approaches based on high resolution data, although powerful, are mainly used at the local scale. We showed in the section 3.4.2 that upscaling such data was challenging beyond a few dozen $\mathrm{km}$ of river. However, at this scale, remote sensing would be a particularly useful alternative to field campaigns or photointerpretation. Species classification methods that are more robust to upscaling still need to be developed, as indicated by Fassnacht et al. (2016) in a review of forest tree species classification.

\subsubsection{Physiological processes}

411 Medium-resolution satellite images ( $>10 \mathrm{~m}$ resolution and $\leq 50 \mathrm{~m}$ for most studies) were the most popular type of data used to assess physiological processes of riparian vegetation $(100 \%, 73 \%$ and 
414 One advantage of using these images in this context is that they are often available as dense series, 415 which is useful for studying cyclic processes. For example, Wallace et al. (2013) used AVHRR images (return period $<1$ day) to detect variations in the timing of greening up/scenescing of vegetation. Nagler et al. (2012) used MODIS (return period 1-2 days) to study phases of the life cycle of the tamarix leaf beetle (Diorhabda carinulata) throughout the year. Cadol and Wine (2017) and Nagler et al. (2016) used long-term records (several years) of satellite images along with flow data to investigate relationships between hydrology and physiological processes in riparian vegetation. construction on vegetation health status. Sims and Colloff (2012) used MODIS images over several years to assess responses of riparian vegetation during and after flooding events. However, the low resolution often means that pixels in the image aggregate greater heterogeneity in ground features. Accuracy thus decreases, making it more complicated to study different types of vegetation separately (Tillack et al., 2014; Cunningham et al., 2018). The health status of vegetation is often studied with higher resolution data, occasionally with a single image (Tillack et al., 2014; Michez et al., 2016b; Bucha and Slávik, 2013; Shendryk et al., 2016; Sankey et al., 2016).

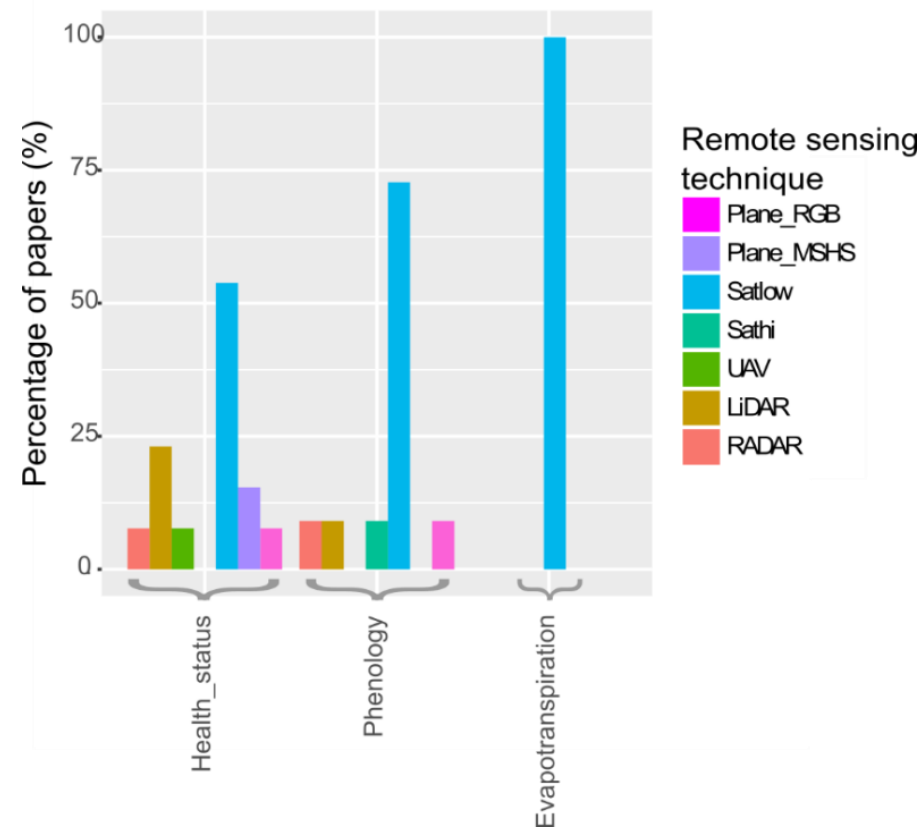


LiDAR appears to be the most used technology for describing vegetation structure features, except for Large Woody Debris, landscape metrics and vegetation cover (Figure 12). LiDAR appears therefore to be the most promising technology for describing vegetation structure and related

435 functions such as shading or surface roughness. The LiDAR signal can penetrate the canopy and the 436 water surface, and provides information about topography under dense canopies, the internal 437 structure of canopies and bathymetry.

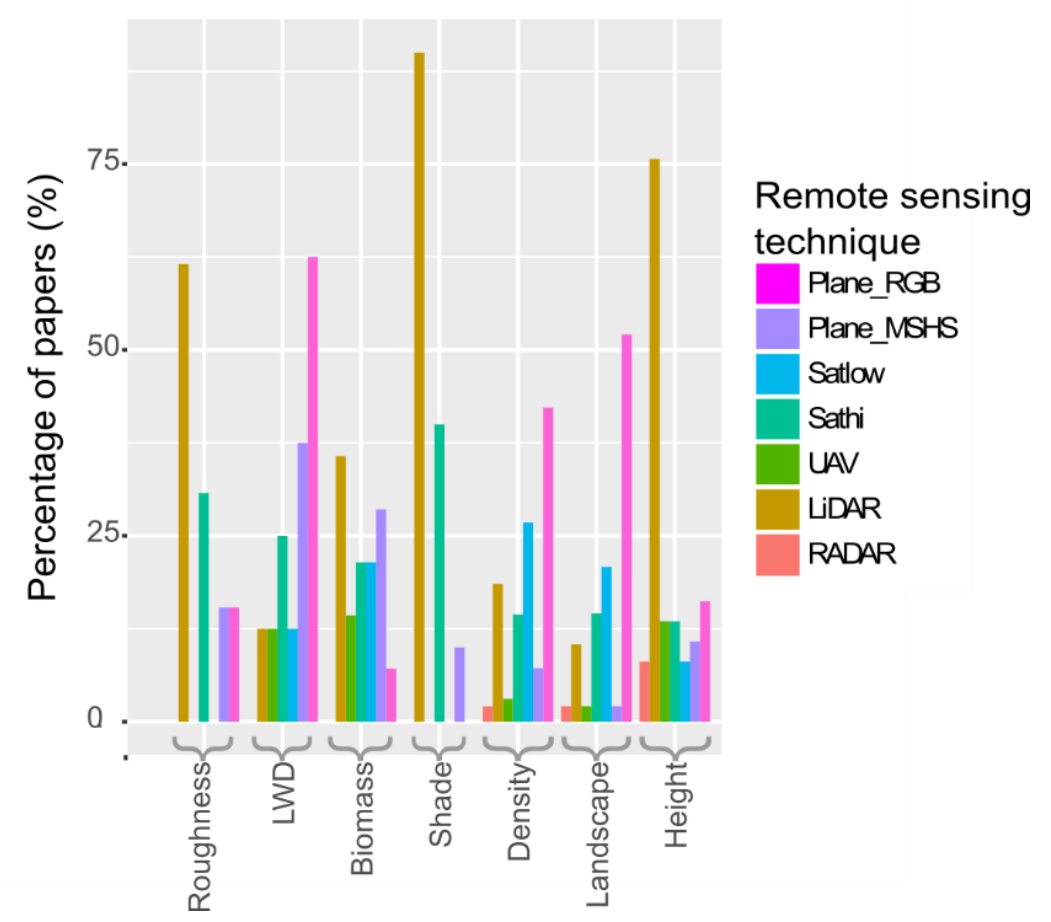

Figure 12. Percentage of studies that used given remote sensing data to map structural features of riparian vegetation.

Retrieving simple structural attributes of vegetation (e.g. height, continuity, overhanging character) is straightforward, since they can be extracted from DTMs, DSMs or CHMs delivered by LiDAR data producers. These applications have reached an operational level. However, further methodological developments for processing the 3D point cloud and new generations of full-waveform LiDAR data must be explored before they can be transfered to management operations. For example, full445 waveform LiDAR data have shown promising results in forestry applications (e.g. Koenig and Höfle, 446 2016), but there are few examples for riparian vegetation (Shendryk et al., 2016). 
LiDAR data have been used in $90 \%$ of studies (Figure 12) to map riparian shade, which is a major

448 parameter that influences stream water temperature (Poole and Berman, 2001). Temperature

449 regulates the habitat of aquatic species such as the brown trout (Salmo trutta fario L.) (Caissie, 2006; Georges et al., 2019), and the effect of riparian shade on stream water temperature is strong enough to affect aquatic communities significantly (Bowler et al., 2012). Field methods used to measure stream shade are expensive and time-consuming (Rutherford et al., 2018). LiDAR data appears to be the most promising alternative because they can describe shade at a fine scale (Richardson et al., 2019). Several methods for using LiDAR data to measure riparian shade have been described in the literature. Richardson et al. (2009) calculated light penetration index raster products as a predictor of light conditions. LiDAR data can describe shadowing properties using a simple CHM derived from point clouds (Michez et al., 2017; Loicq et al., 2018; Wawrzyniak et al., 2017). Other studies have used 3D point clouds to retrieve the finest-scale information about vegetation structure. For example, Akasaka et al. (2010) used a LiDAR point cloud to estimate biomass overhanging the river, while Tompalski et al. (2017) used one to model solar shading on a given summer day. Recently, Shendryk et al. (2016) used full-waveform LiDAR data to estimate the dieback of individual riparian trees, which was related to their shadowing properties.

LiDAR data have also been used in $61 \%$ of studies to map floodplain roughness in a spatially continuous manner (Figure 12). Forzieri et al. (2012) distinguished two main approaches for mapping 465 floodplain roughness using remote sensing: classification-derived mapping and hydrodynamic 466 modeling. In the former, thematic maps of land cover or vegetation classes are produced with remote sensing data. A roughness coefficient (often Manning's coefficient) is then assigned to each class using a lookup table. In the latter, hydrodynamic properties of vegetation are estimated using an indicator of vegetation structure (e.g. leaf area index, stem or crown diameter, vegetation height).

470 LiDAR technology has several advantages in this case: it measures structural attributes directly and

471 can account for complex, multilayered structures (Manners et al., 2013; Jalonen et al., 2015).

472 Hydrodynamic modeling is often combined with classification-derived mapping, with separate 
modeling of hydrodynamic properties of each vegetation class (Straatsma and Baptist, 2008; Zahidi et al., 2018). Development of restoration and multi-objective management practices (to promote ecosystem health while protecting people and goods) has increased demand for models that represent effects of vegetation on flow more accurately (Rubol et al., 2018). However, research on hydrodynamic properties of vegetation and how to measure them in the field is ongoing (Shields et al., 2017).

\subsection{Multi-temporality of remote sensing riparian studies}

Overall, $54 \%$ of studies in the database were multi-temporal (i.e. studies where data acquired at several dates are used to understand the dynamics of riparian vegetation). RGB/GS aerial images were used in more than $60 \%$ of the multi-temporal studies (Figure 13A), such as those of Dufour et al. (2015) or Lallias-Tacon et al. (2017). Such studies usually focus on decadal time scales. It can be explained by the fact that this type of images is simple to use and has been available over a large extent since the 1950s (Dufour et al., 2012). In most of the countries previously highlighted as active in riparian research, public administrations have performed long-term and systematic national aerial surveys for general purposes (e.g. urban planning) that researchers can use at low cost. Most multitemporal studies that included aerial photographs used photointerpretation to describe riparian vegetation features. Medium resolution satellite images were often used in multi-temporal studies, notably for the study of physiological processes (see section 3.5.3). 

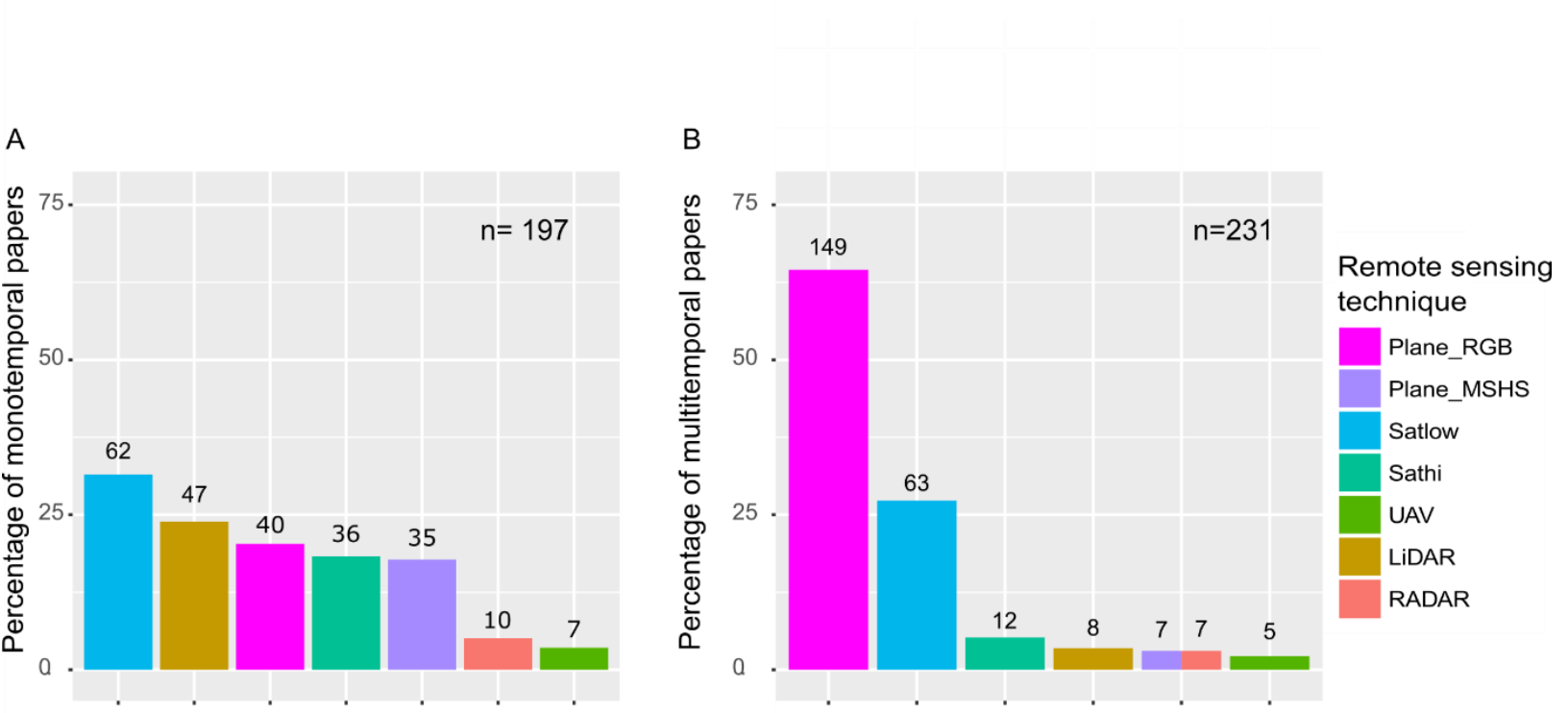

491

493

494

495

496

497

498

499

500

501

502

503

504

505

Figure 13. Use of remote sensing data in (A) multi-temporal and (B) mono-temporal studies (respectively 54\% and $46 \%$ of the studies).

Conversely, more recent technologies (e.g. high-resolution satellite images, LiDAR data) were far more common in studies that focused on one period than in multi-temporal studies (Figure 13B). For example, LiDAR and high-resolution satellite data were used in respectively $24 \%$ and $18 \%$ of monotemporal studies against $4 \%$ and $5 \%$ of multi-temporal studies. In mono-temporal studies, the methods developed to map riparian forest attributes were more complex and mostly automated, such as supervised classifications (Michez et al., 2016b; Antonarakis et al., 2008) and calculation of metrics (Riedler et al., 2015).

We predict that diachronic analyses will be renewed by the increasing quality and availability of remote sensing data. Indeed, data acquired from new sensors, such as LiDAR and hyperspectral sensors, become more and more available as time series. For example, a LiDAR survey covers the entire region of Wallonia (southern Belgium) every six years. In France, in the framework of the Litto3D program, ca. $45,000 \mathrm{~km}^{2}$ of coast (bathymetry included) will be regularly covered with a dense LiDAR survey, in order to monitor sediment dynamics and erosion processes. These new data provide the opportunity to monitor changes in specific features of riparian vegetation, such as canopy height, species composition or fine scale physiological processes. In addition, acquisition 
frequency has increased. For example, UAVs can acquire dense time series easily. High-resolution satellite images such as Sentinel-1 and Sentinel-2 (four bands at $10 \mathrm{~m}$ resolution) provide images of the Earth's entire surface every few days. More recently, CubeSat constellations provide higher resolution and higher frequency. For example, the Dove constellation (Planet Labs, Inc., San Francisco, CA, USA) provides resolution up to $3 \mathrm{~m}$ and daily coverage. This increased frequency of image acquisition provides new opportunities to study rapid riparian vegetation processes, including intra-annual ones such as phenology and impacts of flood events.

\section{Perspectives for riparian vegetation management}

The second objective of this review was to discuss how remote sensing approaches developed by scientists can be used by riparian managers. Research in remote sensing of riparian vegetation often has an applied perspective, and $38 \%$ of the abstracts in our database contained the words "management", "restoration" or their derivatives. However, scientific articles usually do not describe how remote sensing developments are made available to managers, and how they can be implemented in management situations.

Therefore, we completed our systematic review of the literature with an approach based on expert judgment, focusing on how remote sensing developments can be valued as operational tools available to managers. In section 4.1 , we selected five examples of applications for riparian management. For each example, we highlight how remote sensing approaches can be embedded in operational tools, and how scientific developments (previously discussed in section 3) can contribute to these tools. In section 4.2, we further discuss the challenges of knowledge transfer from scientists to managers, illustrated by the five selected examples.

\subsection{Examples of near-operational applications}

We chose three contrasting fields of applications that we considered as particularly relevant for the riparian context: eradication of invasive plant species, monitoring ecological integrity at the regional scale and maintenance of hydraulic conveyance. 
Riparian managers often conduct programs to eradicate invasive plant species. These programs require identifying and locating individuals prior to eradication measures and subsequent monitoring of invasive cover (i.e. to ensure that practices were effective and that the species do not re-emerge)

538 (Vaz et al., 2018). These actions can be perfomed with UAVs that combine high spatial resolution (useful for detecting invasive plant species at an early stage, before they form large clumps) and high temporal resolution (invasive plant species are often more distinct from the background during a particular phenological phase, according to Manfreda et al. (2018)). Many studies have shown that detecting invasive plant species using a UAV could outperform ground surveys in terms of cost, effectiveness and risk mitigation for operators (Martin et al., 2018; Michez et al., 2016a). The detection of invasive plants can be performed using photo-interpretation (most simple method) or a supervised classification (most scalable method) of orthoimages (Hill et al., 2017). In the future, real-

547 steps to be performed at the same time (Hill and Babbar-Sebens, 2019).

548 In order to implement this approach, river managers must have access to skilled staff who are able to 549 pilot the UAV and process the images based on the needs of riparian managers. The staff can be 550 recruited and trained within the organization, or work for an exterior contracting organization. For invasive species, work is often concentrated in time, and skilled staff must be available at that time.

\subsubsection{Examples 2 and 3: Monitoring ecological integrity at the regional scale}

Managers of riparian vegetation at the regional or national scale sometimes need information about the entire river network to assess effects of policies or define management strategies (e.g. to prioritize which zones should be restored). For example, all EU member states must monitor the state of riparian ecosystems to comply with the Water Framework Directive (WFD), which promotes 
They can include remote sensing techniques in different ways. We briefly present two contrasting approaches to include remote sensing in ecological assessments: a sampling- and photointerpretation-based approach using aerial images, or the use of regional LiDAR data to map riparian structural attributes automatically.

In the first approach (hereinafter referred to as example 2), aerial images can be integrated with minor adaptations into a traditional field-based, sampling approach. Aerial images are used to target sampling sites (e.g. where riparian vegetation is present) and to perform certain aspects of the assessment, especially those that require less specific information at a larger scale. For example, the Riparian Quality Index, initially developed for Iberian rivers, includes measurements of width, continuity, strata, composition, regeneration, bank condition, lateral connectivity and substratum (González del Tánago and García de Jalón, 2011). Width, continuity and strata can be described using aerial imagery, while other attributes are assessed in the field.

In the second approach (hereinafter referred to as example 3), regional LiDAR data can be used to assess riparian features in a spatially continuous manner. In this case, the strength of LiDAR data is that the 3D component is homogenous at the regional scale unlike spectral data (see section 3.4.2). Moreover, it can extract attributes of the channel even when it is hidden by vegetation. Riparian attributes are calculated with a high level of automation and can be updated at the same frequency as the actualization frequency of the LiDAR cover. For example, in Wallonia (southern Belgium), Michez et al. (2017) used LiDAR and photogrammetric point clouds to map riparian buffer attributes along $12,000 \mathrm{~km}$ of rivers (vegetation continuity, height and overhang; channel width and sinuosity; and lateral connectivity, indicated by emerged channel depth). The results are meant to be used as decision making tools by river managers. They are made available on an online platform, where river managers must plan their management practices for a six year period.

\subsubsection{Examples 4 and 5: Improving flood modeling with better estimates of} floodplain roughness 

Many regions of the world must address significant and increasing threats of flooding, as well as the need to conserve riparian ecosystems (Straatsma et al., 2019). Floodplain vegetation can influence flood risk by increasing hydraulic roughness (Curran and Hession, 2013). In the Netherlands, where these challenges are particularly acute, several remote sensing applications integrate riparian vegetation management more into flood mitigation strategies.

One example (hereinafter referred to as example 4) includes a legal map produced to describe the maximum roughness of vegetation cover allowed within the floodplains of major Dutch rivers. The legal map uses a historical situation as a target reference (Rijkswaterstaat, 2014). To support use of this legal map, Deltares (an independent applied research institute) and the Rijkswaterstaat (the administration responsible for river management) developed an online vegetation-mapping tool based on free multispectral, high-resolution satellite images. In the Google Earth Engine environment, users can easily classify the vegetation cover observed on recent Sentinel-2 images to ensure that it complies with the legal standard. The tool is available on smartphones and can be used in the field. Actual vegetation can be compared to the map before each winter, when most floods occur. The tool provides information about the areas on which management practices should focus, following a dialogue with the landowners concerned (Penning, 2018).

Modeling approaches are also useful to support decisions. To prevent flood damage in Dutch deltas, multiple practices, such as raising dikes or removing riparian vegetation, must be implemented in a coordinated manner. Straatsma and Kleinhans (2018) developed the RiverScape toolbox. This tool models the effects of riparian cutting on flow using hydrological and spatial data (including a DTM, a vegetation map and its associated roughness coefficients). The RiverScape toolbox (hereinafter referred to as example 5) can optimize the location of cutting operations to reduce water levels during floods.

\subsection{Challenges of conveying tools to managers}


The five examples given in the previous section illustrate that remote sensing approaches can be embedded in operational tools for riparian managers. In this section, we discuss more generally how scientists and managers can collaborate to produce and implement such tools for the management of riparian vegetation.

We distinguish three main steps in this process (Figure 14). First, managers and remote sensing experts must work together to define clear objectives. Second, the development step implies a technological phase. Third, thorough assessment must be performed for accuracy, reliability and relevance for managers. Critical thinking is required throughout this process because the choice of a remote sensing approach is not neutral and has implications for how riparian vegetation is managed.

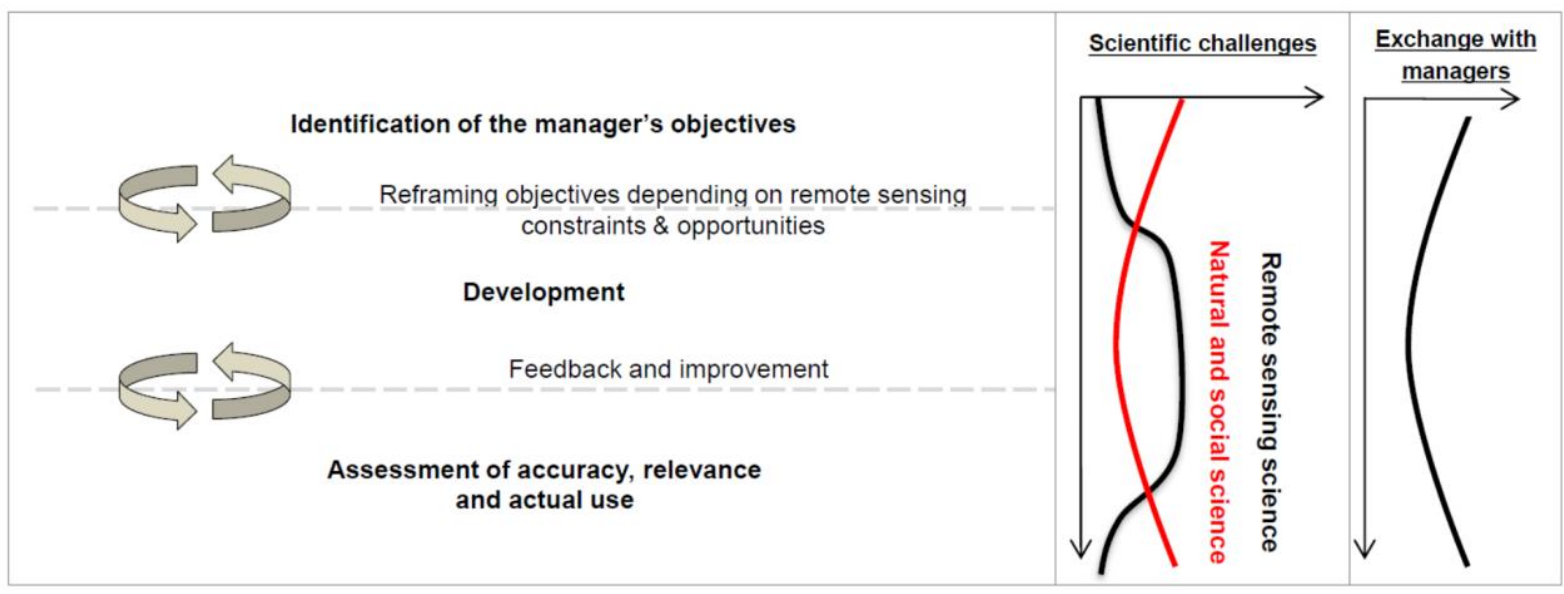

Figure 14. Conceptual framework of the transfer of remote sensing tools from scientists to managers. On the graphics to the right, the horizontal axes represent scientific challenge and exchange degree to be planned between managers and researchers (from low to high), while the vertical axes represent their dynamics from start to finish.

\subsubsection{Identifying the issues/needs of riparian vegetation managers}

The first step in implementing a remotely sensed application is to define the needs and objectives of riparian vegetation managers. Key issues must be addressed, such as the features to be mapped, the scale of observation, the time required to obtain usable information and the frequency of updating. Objectives can be refined during the development step, depending on the tradeoffs between costs and image quality. Nevertheless, thoroughly defining the objectives beforehand is clearly a factor of 
success (Kennedy et al., 2009). In the example 1 (use of UAVs to help eradicate invasive species, section 4.1.1), it is often easier to detect plants at a particular phenological phase. For instance, $H$. Mantegazzianum is easier to detect while flowering, thanks to its characteristic white umbels (Michez et al, 2016a). While this detection period might be appropriate for scientific purposes, it does not fully satisfy eradication requirements, since individuals must be removed before they form fruit, which leaves little time for eradicators to remove them. One must consider that kind of details when developing operational tools for management.

The thorough definition of objectives is not straightforward. To translate monitoring objectives into a remote sensing approach requires an explicit space for collaboration between remote sensing specialists and managers (Kennedy et al., 2009). Managers are often unsure about the operational potential of remote sensing approaches (Vanden Borre et al., 2011). This is increasingly true, since new technologies (e.g. satellites, UAVs) seem to be developed very quickly, and even faster than the applications for using them. Therefore, realistic monitoring objectives must be defined along with remote sensing specialists. Moreover, field and remote sensing approaches often are not perfectly interchangeable (Dufour et al., 2012). Challenging the work routine of managers might be required to fully benefit from remote sensing approaches. The collaborative process should thus be open enough to consider adapting work routines. Similarly, when relevant, managers and scientists from different fields must be involved. It is important to combine a variety of scientific perspectives (e.g. geomatic, landscape planning, riparian ecology) to avoid too narrow or inappropriate solutions.

In many cases at this stage, riparian vegetation is not the center of management operations. Many studies and management operations focus on the river channel and its hydrological and geomorphological components. In the example 5 (modeling the impact of management practices on flood hazard, section 4.1.3), the RiverScape toolbox does not only consider riparian cuttings but also raising dykes or lowering floodplain level.

\subsubsection{Developing applications that use remote sensing data}


652 Once the objectives have been clearly identified, the next step is to develop the solution to use

653 remote sensing data to pursue the manager's objectives. Several stakeholders are involved in this process. We artificially distinguish "data producers" from the "developers".

We consider "data producers" the stakeholders who provide rough datasets, such as raw satellite images or raw ancillary data (e.g. national space agencies such as NASA and CNES, UAV constructors). While they do not interact closely with riparian vegetation managers, their role is important in the long run since they set the agenda for the main future developments of new remote sensing technologies. More directly, they can promote the use of remote sensing data for natural resource managers by making the data affordable and easier to use, as mentioned in section 3.1. In the example 4 (floodplain roughness monitoring with Google Earth Engine, section 4.1.3), the classification of vegetation in the floodplain is made possible by the availability of free temporal series of Sentinel-2 images.

We consider "developers" the stakeholders who develop tools that use raw remote sensing data. They may interact more closely with riparian vegetation managers and provide solutions that are tailored to the latter's needs through the previously mentioned space for collaboration. The main stakeholders in this category are academic and research institutes, as well as commercial or nonacademic organizations, which use remote sensing data. In theory, the needs identified define the type of stakeholders involved. For example, if the manager's issue has scientific relevance (e.g. understanding the spread of an invasive species not studied before), academics would logically be

671 involved. If no scientific issue is identified, however, then commercial or non-academic organizations are more appropriate.

673 Simple remote sensing approaches can be sometimes be deployed with only minor investment, such as the monitoring of riparian quality attributes with aerial images described in the example 2 (section 4.1.2). However, the fixed costs of implementing a remote sensing approach are often relatively high 
677 the market. These costs include designing the method, deploying the platform or acquiring the 678 minimum number of satellite images and possibly training personnel. Moreover, performing certain 679 analyses requires technical skills (e.g. object-based image analysis, machine learning approaches, LiDAR full waveform analysis). Therefore, remote sensing could have greater relevance when the area to be mapped is large and/or the operation must be repeated several times (Johansen et al., 2007). The approach deployed in the example 3 (monitoring river networks with LiDAR data) is efficient because it concerns $12.000 \mathrm{~km}$ of rivers and it is to be repeated every 6 years. However, many stakeholders with different objectives are generally involved, since riparian vegetation covers large geographical areas. This can reduce the potential for economies of scale, whether for river managers trying to develop their own expertise or for businesses offering their services. This narrow market provides relatively limited opportunities for companies to develop specific tools adapted for this vegetation type. Indeed, we do not expect specific UAV applications to become as developed for managing invasive species in riparian areas (see example 1 in section 4.1.1) as they are for precision agriculture.

To address the challenge of attaining "critical mass" for riparian vegetation, we suggest a more collaborative approach, as described by Steiniger and Hay (2009). Processing routines developed by remote sensing scientists could be embedded into OpenAccess toolboxes. To benefit a large audience, these tools must be robust by having little sensitivity to situations that differ slightly from those for which they were created. For managers to use them, they need to be flexible and integrate easily with other processing routines or platforms (e.g. GIS platforms) (Vanden Borre et al., 2011). Finally, they should be based on widely available data: the tool presented in the example 4 (floodplain roughness monitoring using Sentinel images in the Netherlands, section 4.1.3) could potentially be replicated in many regions since Sentinel-2 images are available worldwide. OpenAccess tools for river or ecosystem management could be collected in community repositories along with other tools for river or ecosystem management, along with freely available datasets, as 
suggested by Tomsett and Leyland (2019) or Piégay et al (2020). These tools could form a foundation that commercial companies, researchers and managers could adapt to specific projects.

\subsubsection{Assessment and feedback}

The final step in conveying remote sensing tools to riparian managers involves accurate and effective assessment of the maps produced and the potential for future monitoring. Accuracy involves the statistical validity of the product, which is the conformity of the map to reference data (e.g. thematic accuracy, in the case of classification). This step is crucial because it indicates the extent to which the map can be trusted. Remote sensing specialists usually consider it a central element, although controversy remains on the reliability of popular accuracy assessment methods (Pontius and Millones, 2011). Moreover, users must be cautious when reproducing the method at another site, since accuracy is often assessed for small test sites, and robustness is often not assessed sufficiently (Fassnacht et al., 2016).

However, the relevance of a remote sensing approach cannot be reduced to its accuracy. The relevance of the information for management purposes must consider the costs and benefits of obtaining such information (Kennedy et al., 2009). We argue that temporality should be considered when addressing this aspect. The true effectiveness of a tool is often observed long after it is first produced. Moreover, the issue of using remote sensing data in future monitoring (or not) must be considered. For example, after a restoration action, vegetation must be monitored in the short term (i.e. after one year) and the long term (i.e. after 5-10 years). Consequently, it is important to define which stakeholders are involved in this future monitoring (the initial producer of the map, the managers themselves or an external stakeholder) and which methods will be used. If managers are in charge of future monitoring, training should be provided. The example 2 (monitoring of riparian quality attributes with aerial images, see section 4.1.2) only requires basic training in GIS and photointerpretation. However, for the example 3 (monitoring river networks with LiDAR data), training 
courses that include programming must be provided to river managers, in order to enable them to update riparian indicators based on future regional LiDAR coverage.

The ease of use of the tools developed and their integration into existing workflows are also central aspects determining whether a manager will adopt remote sensing tools (Vanden Borre et al., 2011). We argue that it is crucial to obtain feedback from managers about the real use of the maps and features produced using remote sensing data. This feedback would help to develop tools that are more adapted to the managers' needs.

\subsubsection{Issues beyond the remote sensing discipline}

The development and use of remote sensing tools to manage riparian vegetation is not only a technical issue. It raises at least two particular issues that must be addressed in an interdisciplinary or even transdisciplinary manner. First, the information must be scientifically relevant from a thematic perspective. In the example 3 (section 4.1.2), LiDAR data make it possible to measure vegetation height or continuity. However, whether this information is sufficient or relevant to assess a particular function of riparian vegetation must be discussed with experts from different disciplines (e.g. ecologists, hydrologists). Second, critical feedback about the use of remote sensing tools is also needed afterwards. Using these tools to assess environmental patterns and processes or to map natural resources is clearly not neutral. In some cases, these methods exclude certain stakeholders who do not have access to the technology, limit the understanding of certain complex phenomena and generate controversial data (e.g. Fairhead and Leach, 1998; Harwell, 2000; Turner and Taylor, 2003; Rajão, 2013). In the example 5 (section 4.1.3), the RiverScape tool helps managers finding the best location for practices that aim to reduce flood hazard. However, the tool is not meant to be used alone to make decisions. Within a larger governance system, it can help stakeholders find a common ground through providing a large scale perspective, and through highlighting tradeoffs between stakes and stakeholders (Straatsma et al, 2019). More generally, sociological and cultural effects must be understood, and adverse effects of using remote sensing for natural resource 
management should be properly handled. Social scientists should be involved throughout the process to address these issues.

\section{Conclusion}

We found a substantial body of literature in which remote sensing was used to study riparian vegetation. Remote sensing became considerably popular at the turn of the millennium, but its relative use in riparian vegetation studies remains limited (ca. 4\%), and mostly in developed countries. In order to increase the user base, scientists can develop approaches that are robust to slight context changes and that take advantage of widely available data. These approaches can be embedded in Open Access or easy-to-use tools. The production, dissemination and use of large or global datasets concerning rivers, floodplains or land cover should also be promoted.

Development of new sensors and platforms has improved remote sensing approaches. However, most studies that use newer sensors and platforms focus on the local-to-river segment scale. Largescale studies are based on medium-resolution satellite images. Algorithms are needed to process high-resolution data that is robust to upscaling. Spectral heterogeneity makes upscaling the study of species composition using spectral data more challenging than upscaling the study of vegetation structure using 3D data.

Riparian vegetation is highly dynamic, and the multi-temporal nature of riparian remote sensing studies is central (54\% of studies are multi-temporal). To date, diachronic analyses have relied essentially on aerial photographs, and it is clear that these data will remain popular given their availability and simplicity of use. However, other data time series become increasingly available. Scientists should test using these data to study complex and subtle phenomena, beyond changes in the extent of riparian forests or plant succession. For example, temporal series of LiDAR data should be tested to map subtle changes in vegetation structure such as growth, regeneration or senescence. Higher resolution or more frequent satellite images could help understand physiological or 
community responses of riparian vegetation to environmental stress over large extents, yet at a finer spatial or temporal scale than before.

It is often suggested that remote sensing approaches can contribute to management of riparian vegetation by providing objective, continuous and up-to-date data for a large area. This contribution was difficult to determine via a review of the scientific literature, and an extensive review of the gray literature could provide further insight into this subject. However, there are many examples of operational or near-operational applications, not only with aerial images but also with more recent data (LiDAR, UAVs and satellite images). We suggest that a collaborative effort is required to make remote sensing approaches more robust and available, both in terms of cost and ease of use. However, implementing a remote sensing approach in actual management context still requires a tailored approach. It must include managers and scientists (thematicians and remote sensing scientists), be structured around well-defined objectives and include sufficient feedback.

\section{Acknowledgement}

The collaboration that led to the writing of this article was initiated during a short term scientific mission financed by the Converges COST action (CA16208). This work received financial support from the Province of Liège, the Province of Luxembourg and the Agence de l'eau Seine Normandie.

\section{References}

Akasaka, T., Akasaka, M., Yanagawa, H., 2010. Relative importance of the environmental factors at site and landscape scales for bats along the riparian zone. Landsc. Ecol. Eng. 6, 247-255. https://doi.org/10.1007/s11355-010-0105-4

Alaibakhsh, M., Emelyanova, I., Barron, O., Sims, N., Khiadani, M., Mohyeddin, A., 2017. Delineation of riparian vegetation from Landsat multi-temporal imagery using PCA. Hydrol. Process. 31, 800-810. https://doi.org/10.1002/hyp.11054 
Anderson, K., Gaston, K.J., 2013. Lightweight unmanned aerial vehicles will revolutionize spatial ecology. Front. Ecol. Environ. 11, 138-146. https://doi.org/10.1890/120150

Antonarakis, A.S., Richards, K.S., Brasington, J., 2008. Object-based land cover classification using airborne LiDAR. Remote Sens. Environ. 112, 2988-2998. https://doi.org/10.1016/j.rse.2008.02.004

Arroyo, L.A., Johansen, K., Armston, J., Phinn, S., 2010. Integration of LiDAR and QuickBird imagery for mapping riparian biophysical parameters and land cover types in Australian tropical savannas. For. Ecol. Manag. 259, 598-606. https://doi.org/10.1016/j.foreco.2009.11.018

Ashraf, S., Brabyn, L., Hicks, B.J., Collier, K., 2010. Satellite remote sensing for mapping vegetation in New Zealand freshwater environments: A review. N. Z. Geogr. 66, 33-43. https://doi.org/10.1111/j.1745-7939.2010.01168.x

Beechie, T., Pess, G., Roni, P., Giannico, G., 2008. Setting river restoration priorities: a review of approaches and a general protocol for identifying and prioritizing actions. North Am. J. Fish. Manag. 28, 891-905.

Belletti, B., Dufour, S., Piégay, H., 2015a. What is the Relative Effect of Space and Time to Explain the Braided River Width and Island Patterns at a Regional Scale? River Res. Appl. 31, 1-15. https://doi.org/10.1002/rra.2714

Belluco, E., Camuffo, M., Ferrari, S., Modenese, L., Silvestri, S., Marani, A., Marani, M., 2006. Mapping salt-marsh vegetation by multispectral and hyperspectral remote sensing. Remote Sens. Environ. 105, 54-67. https://doi.org/10.1016/j.rse.2006.06.006

Bendix, J., Stella, J.C., 2013. Riparian Vegetation and the Fluvial Environment: A Biogeographic Perspective. Treatise Geomorphol. 53-74. https://doi.org/10.1016/B978-0-12-374739$6.00322-5$

Bertoldi, W., Drake, N.A., Gurnell, A.M., 2011. Interactions between river flows and colonizing vegetation on a braided river: exploring spatial and temporal dynamics in riparian vegetation 

cover using satellite data. Earth Surf. Process. Landf. 36, 1474-1486. https://doi.org/10.1002/esp.2166

Bowler, D.E., Mant, R., Orr, H., Hannah, D.M., Pullin, A.S., 2012. What are the effects of wooded riparian zones on stream temperature? Environ. Evid. 1, 3. https://doi.org/10.1186/20472382-1-3

Brogna, D., Dufrêne, M., Michez, A., Latli, A., Jacobs, S., Vincke, C., \& Dendoncker, N. (2018). Forest cover correlates with good biological water quality. Insights from a regional study (Wallonia, Belgium). Journal of Environmental Management, 211, 9-21. https://doi.org/10.1016/j.jenvman.2018.01.017

Bucha, T., Slávik, M., 2013. Improved methods of classification of multispectral aerial photographs: Evaluation of floodplain forests in the inundation area of the Danube. Folia For. Pol. Ser. For. 55. https://doi.org/10.2478/ffp-2013-0007

Bunn, S.E., Abal, E.G., Smith, M.J., Choy, S.C., Fellows, C.S., Harch, B.D., Kennard, M.J., Sheldon, F., 2010. Integration of science and monitoring of river ecosystem health to guide investments in catchment protection and rehabilitation. Freshw. Biol. 55, 223-240. https://doi.org/10.1111/j.1365-2427.2009.02375.x

Cadol, D., Wine, M.L., 2017. Geomorphology as a first order control on the connectivity of riparian ecohydrology. Geomorphology, Connectivity in Geomorphology from Binghamton 2016 277, 154-170. https://doi.org/10.1016/j.geomorph.2016.06.022

Caissie, D., 2006. The thermal regime of rivers: a review. Freshw. Biol. 51, 1389-1406. https://doi.org/10.1111/j.1365-2427.2006.01597.x

Capon, S.J., Pettit, N.E., 2018. Turquoise is the new green: Restoring and enhancing riparian function in the Anthropocene. Ecol. Manag. Restor. 19, 44-53. https://doi.org/10.1111/emr.12326

Carbonneau, P., Piégay, H., 2012. Future prospects and challenges for river scientists and managers, in: Fluvial Remote Sensing for Science and Management. John Wiley \& Sons, Ltd. https://doi.org/10.1002/9781119940791 
Carli, C.M., Bayley, S.E., 2015. River connectivity and road crossing effects on floodplain vegetation of the upper Columbia River, Canada. Écoscience 22, 97-107. https://doi.org/10.1080/11956860.2015.1121705

Claggett, P.R., Okay, J.A., Stehman, S.V., 2010. Monitoring Regional Riparian Forest Cover Change Using Stratified Sampling and Multiresolution Imagery1. JAWRA J. Am. Water Resour. Assoc. 46, 334-343. https://doi.org/10.1111/j.1752-1688.2010.00424.x

Congalton, R.G., Birch, K., Jones, R., Schriever, J., 2002. Evaluating remotely sensed techniques for mapping riparian vegetation. Comput. Electron. Agric. 37, 113-126. https://doi.org/10.1016/S0168-1699(02)00108-4

Cunningham, S.C., Griffioen, P., White, M.D., Nally, R.M., 2018. Assessment of ecosystems: A system for rigorous and rapid mapping of floodplain forest condition for Australia's most important river. Land Degrad. Dev. 29, 127-137. https://doi.org/10.1002/Idr.2845

Curran, J.C., Hession, W.C., 2013. Vegetative impacts on hydraulics and sediment processes across the fluvial system. J. Hydrol. 505, 364-376. https://doi.org/10.1016/j.jhydrol.2013.10.013

Cushnie, J. L., 1987. The interactive effect of spatial resolution and degree of internal variability within land-cover types on classification accuracies. International Journal of Remote Sensing, 8(1), 15-29. https://doi.org/10.1080/01431168708948612

Dahm, C.N., Cleverly, J.R., Coonrod, J.E.A., Thibault, J.R., Mcdonnell, D.E., Gilroy, D.J., 2002. Evapotranspiration at the land/water interface in a semi-arid drainage basin. Freshw. Biol. 47, 831-843. https://doi.org/10.1046/j.1365-2427.2002.00917.x

Dauwalter, D.C., Fesenmyer, K.A., Bjork, R., 2015. Using Aerial Imagery to Characterize Redband Trout Habitat in a Remote Desert Landscape. Trans. Am. Fish. Soc. 144, 1322-1339. https://doi.org/10.1080/00028487.2015.1088471

Debruxelles, N., Claessens, H., Lejeune, P., \& Rondeux, J., 2009. Design of a watercourse and riparian strip monitoring system for environmental management. Environmental Monitoring and Assessment, 156(1-4), 435-450. https://doi.org/10.1007/s10661-008-0496-y 
Décamps, H., 2001. How a riparian landscape finds form and comes alive. Landscape and Urban Planning, 57(3), 169-175. https://doi.org/10.1016/S0169-2046(01)00202-X

Dixon, S. J., Sear, D. A., Odoni, N. A., Sykes, T., \& Lane, S. N., 2016. The effects of river restoration on catchment scale flood risk and flood hydrology. Earth Surface Processes and Landforms, 41(7), 997-1008. https://doi.org/10.1002/esp.3919

Doody, T.M., Lewis, M., Benyon, R.G., Byrne, G., 2014. A method to map riparian exotic vegetation (Salix spp.) area to inform water resource management. Hydrol. Process. 28, 3809-3823. https://doi.org/10.1002/hyp.9916

Dufour, S., Piégay, H., 2009. From the myth of a lost paradise to targeted river restoration: forget natural references and focus on human benefits. River Res. Appl. 25, 568-581. https://doi.org/10.1002/rra.1239

Dufour, S., Muller, E., Straatsma, M., Corgne, S., 2012. Image Utilisation for the Study and Management of Riparian Vegetation: Overview and Applications, in: Fluvial Remote Sensing for Science and Management. John Wiley \& Sons, Ltd. https://doi.org/10.1002/9781119940791

Dufour, S., Bernez, I., Betbeder, J., Corgne, S., Hubert-Moy, L., Nabucet, J., Rapinel, S., Sawtschuk, J., Trollé, C., 2013. Monitoring restored riparian vegetation: how can recent developments in remote sensing sciences help? Knowl. Manag. Aquat. Ecosyst. 10. https://doi.org/10.1051/kmae/2013068

Dufour, S., Rinaldi, M., Piégay, H., Michalon, A., 2015. How do river dynamics and human influences affect the landscape pattern of fluvial corridors? Lessons from the Magra River, CentralNorthern Italy. Landsc. Urban Plan. 134, 107-118. https://doi.org/10.1016/j.landurbplan.2014.10.007

Dufour, S., Rodríguez-González, P.M., Laslier, M., 2019. Tracing the scientific trajectory of riparian vegetation studies: Main topics, approaches and needs in a globally changing world. Sci. Total Environ. 653, 1168-1185. https://doi.org/10.1016/j.scitotenv.2018.10.383 
Dunford, R., Michel, K., Gagnage, M., Piégay, H., Trémelo, M.-L., 2009. Potential and constraints of Unmanned Aerial Vehicle technology for the characterization of Mediterranean riparian forest. Int. J. Remote Sens. 30, 4915-4935. https://doi.org/10.1080/01431160903023025

Dutta, D., Wang, K., Lee, E., Goodwell, A., Woo, D.K., Wagner, D., Kumar, P., 2017. Characterizing Vegetation Canopy Structure Using Airborne Remote Sensing Data. IEEE Trans. Geosci. Remote Sens. 55, 1160-1178. https://doi.org/10.1109/TGRS.2016.2620478

Fairhead, J., Leach, M., 1998. Reconsidering the extent of deforestation in twentieth century West Africa. Unasylva 49192 38-46.

Fassnacht, F.E., Latifi, H., Stereńczak, K., Modzelewska, A., Lefsky, M., Waser, L.T., Straub, C., Ghosh, A., 2016. Review of studies on tree species classification from remotely sensed data. Remote Sens. Environ. 186, 64-87. https://doi.org/10.1016/j.rse.2016.08.013

Fausch, K.D., Torgersen, C.E., Baxter, C.V., Li, H.W., 2002. Landscapes to Riverscapes: Bridging the Gap between Research and Conservation of Stream Fishes. BioScience 52, 483-498. https://doi.org/10.1641/0006-3568(2002)052[0483:LTRBTG]2.0.CO;2

Fédération des Conservatoires d'espaces naturels, 2018. Les nouvelles technologies dans l'étude des milieux humides : exemples d'applications.

Fernandes, M.R., Aguiar, F.C., Ferreira, M.T., Pereira, J.M.C., 2013a. Spectral separability of riparian forests from small and medium-sized rivers across a latitudinal gradient using multispectral imagery. Int. J. Remote Sens. 34, 2375-2401.

https://doi.org/10.1080/01431161.2012.744491

Fernandes, M.R., Aguiar, F.C., Silva, J.M.N., Ferreira, M.T., Pereira, J.M.C., 2013b. Spectral discrimination of giant reed (Arundo donax L.): A seasonal study in riparian areas. ISPRS J. Photogramm. Remote Sens. 80, 80-90. https://doi.org/10.1016/j.isprsjprs.2013.03.007

Fernandes, M.R., Aguiar, F.C., Silva, J.M.N., Ferreira, M.T., Pereira, J.M.C., 2014. Optimal attributes for the object based detection of giant reed in riparian habitats: A comparative study 
between Airborne High Spatial Resolution and WorldView-2 imagery. Int. J. Appl. Earth Obs. Geoinformation 32, 79-91. https://doi.org/10.1016/j.jag.2014.03.026

928

929

930

931

932

933

934

935

936

Forzieri, G., Castelli, F., Preti, F., 2012. Advances in remote sensing of hydraulic roughness. Int. J. Remote Sens. 33, 630-654. https://doi.org/10.1080/01431161.2010.531788

Forzieri, G., Tanteri, L., Moser, G., Catani, F., 2013. Mapping natural and urban environments using airborne multi-sensor ADS40-MIVIS-LiDAR synergies. Int. J. Appl. Earth Obs. Geoinformation 23, 313-323. https://doi.org/10.1016/j.jag.2012.10.004

Fullerton, A.H., Beechie, T.J., Baker, S.E., Hall, J.E., Barnas, K.A., 2006. Regional patterns of riparian characteristics in the interior Columbia River basin, Northwestern USA: applications for restoration planning. Landsc. Ecol. 21, 1347-1360. https://doi.org/10.1007/s10980-006$0017-8$

Georges, B., Brostaux, Y., Claessens, H., Degré, A., Huylenbroeck, L., Lejeune, P., Piégay, H., Michez, A., 2019. Can water level stations be used for thermal assessment in aquatic ecosystem? River Res. Appl. 1 - 14. https://doi.org/10.1002/rra.3520

Gergel, S.E., Stange, Y., Coops, N.C., Johansen, K., Kirby, K.R., 2007. What is the Value of a Good Map? An Example Using High Spatial Resolution Imagery to Aid Riparian Restoration. Ecosystems 10, 688-702. https://doi.org/10.1007/s10021-007-9040-0

Goetz, W.E., 2002. Developing a predictive model for identifying riparian communities at an ecoregion scale in Idaho and Wyoming. Unpublished master thesis, Utah State University, Logan.

Goetz, S.J., 2006. Remote Sensing of Riparian Buffers: Past Progress and Future Prospects. JAWRA J. Am. Water Resour. Assoc. 42, 133-143. https://doi.org/10.1111/j.1752-1688.2006.tb03829.x Gong, P., Wang, J., Yu, Le, Zhao, Yongchao, Zhao, Yuanyuan, Liang, L., Niu, Z., Huang, X., Fu, H., Liu, S., Li, C., Li, X., Fu, W., Liu, C., Xu, Y., Wang, X., Cheng, Q., Hu, L., Yao, W., Zhang, Han, Zhu, P., Zhao, Z., Zhang, Haiying, Zheng, Y., Ji, L., Zhang, Y., Chen, H., Yan, A., Guo, J., Yu, Liang, Wang, L., Liu, X., Shi, T., Zhu, M., Chen, Y., Yang, G., Tang, P., Xu, B., Giri, C., Clinton, N., Zhu, Z., 
Chen, Jin, Chen, Jun, 2013. Finer resolution observation and monitoring of global land cover: first mapping results with Landsat TM and ETM+ data. Int. J. Remote Sens. 34, 2607-2654. https://doi.org/10.1080/01431161.2012.748992

Gong, Z., Cui, T., Pu, R., Lin, C., Chen, Y., 2015. Dynamic simulation of vegetation abundance in a reservoir riparian zone using a sub-pixel Markov model. Int. J. Appl. Earth Obs. Geoinformation 35, 175-186. https://doi.org/10.1016/j.jag.2014.09.004

González del Tánago, M., García de Jalón, D., 2011. Riparian Quality Index (RQI): a methodology for characterising and assessing the environmental conditions of riparian zones. Limnética 30, 0235-0254.

González del Tánago, M., Bejarano, M.D., García de Jalón, D., Schmidt, J.C., 2015. Biogeomorphic responses to flow regulation and fine sediment supply in Mediterranean streams (the Guadalete River, southern Spain). J. Hydrol. 528, 751-762. https://doi.org/10.1016/j.jhydrol.2015.06.065

González, E., González-Sanchis, M., Cabezas, Á., Comín, F.A., Muller, E., 2010. Recent Changes in the Riparian Forest of a Large Regulated Mediterranean River: Implications for Management. Environ. Manage. 45, 669-681. https://doi.org/10.1007/s00267-010-9441-2

González, E., Sher, A.A., Tabacchi, E., Masip, A., Poulin, M., 2015. Restoration of riparian vegetation: A global review of implementation and evaluation approaches in the international, peerreviewed literature. J. Environ. Manage. 158, 85-94. https://doi.org/10.1016/j.jenvman.2015.04.033

Groeneveld, D.P., Watson, R.P., 2008. Near-infrared discrimination of leafless saltcedar in wintertime Landsat TM. Int. J. Remote Sens. 29, 3577-3588. https://doi.org/10.1080/01431160701711078

Hamandawana, H., Chanda, R., 2013. Environmental change in and around the Okavango Delta during the nineteenth and twentieth centuries. Reg. Environ. Change 13, 681-694. https://doi.org/10.1007/s10113-012-0367-5 
Harwell, E., 2000. Remote Sensibilities: Discourses of Technology and the Making of Indonesia's Natural Disaster. Dev. Change 31, 307-340. https://doi.org/10.1111/1467-7660.00156

Henshaw, A. J., Gurnell, A. M., Bertoldi, W., \& Drake, N. A., 2013. An assessment of the degree to which Landsat TM data can support the assessment of fluvial dynamics, as revealed by changes in vegetation extent and channel position, along a large river. Geomorphology, 202, 74-85. https://doi.org/10.1016/j.geomorph.2013.01.011

Hering, D., Borja, A., Carstensen, J., Carvalho, L., Elliott, M., Feld, C.K., Heiskanen, A.-S., Johnson, R.K., Moe, J., Pont, D., Solheim, A.L., de Bund, W. van, 2010. The European Water Framework Directive at the age of 10: A critical review of the achievements with recommendations for the future. Sci. Total Environ. 408, 4007-4019. https://doi.org/10.1016/j.scitotenv.2010.05.031

Hill, D. J., Tarasoff, C., Whitworth, G. E., Baron, J., Bradshaw, J. L., \& Church, J. S., 2017. Utility of unmanned aerial vehicles for mapping invasive plant species: A case study on yellow flag iris (Iris pseudacorus L.). International Journal of Remote Sensing, 38(8-10), 2083-2105. https://doi.org/10.1080/01431161.2016.1264030

Hill, D. J., Babbar-Sebens, M., 2019. Promise of UAV-Assisted Adaptive Management of Water Resources Systems. J. Water Resour. Plan. Manag. 145, 02519001. https://doi.org/10.1061/(ASCE)WR.1943-5452.0001081

Holmes, P. M., Richardson, D. M., Esler, K. J., Witkowski, E. T. F., \& Fourie, S., 2005. A decision-making framework for restoring riparian zones degraded by invasive alien plants in South Africa: Review article. South African Journal of Science, 101(11-12), 553-564.

Honey-Rosés, J., Acuña, V., Bardina, M., Brozović, N., Marcé, R., Munné, A., Sabater, S., Termes, M., Valero, F., Vega, À., \& Schneider, D. W., 2013. Examining the Demand for Ecosystem Services: The Value of Stream Restoration for Drinking Water Treatment Managers in the Llobregat River, Spain. Ecological Economics, 90, 196-205. https://doi.org/10.1016/j.ecolecon.2013.03.019 
Hughes, F. M. R., del Tánago, M. G., \& Mountford, J. O., 2012. Restoring Floodplain Forests in Europe. In J. Stanturf, P. Madsen, \& D. Lamb (Eds.), A Goal-Oriented Approach to Forest Landscape Restoration (pp. 393-422). Springer Netherlands. https://doi.org/10.1007/978-94-007-53389_15

Hupp, C.R., 1992. Riparian Vegetation Recovery Patterns Following Stream Channelization: A Geomorphic Perspective. Ecology 73, 1209-1226. https://doi.org/10.2307/1940670

Jalonen, J., Järvelä, J., Virtanen, J.-P., Vaaja, M., Kurkela, M., Hyyppä, H., 2015. Determining Characteristic Vegetation Areas by Terrestrial Laser Scanning for Floodplain Flow Modeling. Water 7, 420-437. https://doi.org/10.3390/w7020420

Jansen, B.J.M., Backx, J.J.G.M., 1998. Biologische monitoring zoete rijkswateren : ecotopenkartering Rijntakken-oost 1997, RIZA rapport;98.054. RIZA, Lelystad.

Johansen, K., Phinn, S., Dixon, I., Douglas, M., Lowry, J., 2007. Comparison of image and rapid field assessments of riparian zone condition in Australian tropical savannas. For. Ecol. Manag. 240, 42-60. https://doi.org/10.1016/j.foreco.2006.12.015

Johansen, K., Phinn, S., Witte, C., 2010. Mapping of riparian zone attributes using discrete return LiDAR, QuickBird and SPOT-5 imagery: Assessing accuracy and costs. Remote Sens. Environ. 114, 2679-2691. https://doi.org/10.1016/j.rse.2010.06.004

Kalliola, R., Puhakka, M., 1988. River Dynamics and Vegetation Mosaicism: A Case Study of the River Kamajohka, Northernmost Finland. J. Biogeogr. 15, 703-719. https://doi.org/10.2307/2845334

Kennedy, R.E., Townsend, P.A., Gross, J.E., Cohen, W.B., Bolstad, P., Wang, Y.Q., Adams, P., 2009. Remote sensing change detection tools for natural resource managers: Understanding concepts and tradeoffs in the design of landscape monitoring projects. Remote Sens. Environ., Monitoring Protected Areas 113, 1382-1396. https://doi.org/10.1016/j.rse.2008.07.018 
Klein, L. R., Hendrix, W. G., Lohr, V. I., Kaytes, J. B., Sayler, R. D., Swanson, M. E., Elliot, W. J., \& Reganold, J. P., 2015. Linking ecology and aesthetics in sustainable agricultural landscapes: Lessons from the Palouse region of Washington, U.S.A. Landscape and Urban Planning, 134, 195-209. https://doi.org/10.1016/j.landurbplan.2014.10.019

Koenig, K., Höfle, B., 2016. Full-Waveform Airborne Laser Scanning in Vegetation Studies-A Review of Point Cloud and Waveform Features for Tree Species Classification. Forests 7, 198. https://doi.org/10.3390/f7090198

Lallias-Tacon, S., Liébault, F., Piégay, H., 2017. Use of airborne LiDAR and historical aerial photos for characterising the history of braided river floodplain morphology and vegetation responses. CATENA, Geoecology in Mediterranean mountain areas. Tribute to Professor José María García Ruiz 149, 742-759. https://doi.org/10.1016/j.catena.2016.07.038

Landon, N., Piégay, H., Bravard, J.P., 1998. The Drôme river incision (France): from assessment to management. Landsc. Urban Plan. 43, 119-131. https://doi.org/10.1016/S01692046(98)00046-2

Laslier, M., Hubert-Moy, L., Dufour, S., 2019. Mapping Riparian Vegetation Functions Using 3D Bispectral LiDAR Data. Water 11, 483. https://doi.org/10.3390/w11030483

Lattin, P. D., Wigington, P. J., Moser, T. J., Peniston, B. E., Lindeman, D. R., \& Getter, D. R., 2004. Influence of Remote Sensing Imagery Source on Quantification of Riparian Land Cover/Land Use1. JAWRA Journal of the American Water Resources Association, 40(1), 215-227. https://doi.org/10.1111/j.1752-1688.2004.tb01020.x

Lee, P., Smyth, C., Boutin, S., 2004. Quantitative review of riparian buffer width guidelines from Canada and the United States. J. Environ. Manage. 70, 165-180. https://doi.org/10.1016/j.jenvman.2003.11.009

Loicq, P., Moatar, F., Jullian, Y., Dugdale, S.J., Hannah, D.M., 2018. Improving representation of riparian vegetation shading in a regional stream temperature model using LiDAR data. Sci. Total Environ. 624, 480-490. https://doi.org/10.1016/j.scitotenv.2017.12.129 
Macfarlane, W.W., McGinty, C.M., Laub, B.G., Gifford, S.J., 2017. High-resolution riparian vegetation mapping to prioritize conservation and restoration in an impaired desert river. Restor. Ecol. 25, 333-341. https://doi.org/10.1111/rec.12425

Nally, R. M., Cunningham, S. C., Baker, P. J., Horner, G. J., \& Thomson, J. R., 2011. Dynamics of Murray-Darling floodplain forests under multiple stressors: The past, present, and future of an Australian icon. Water Resources Research, 47(12). https://doi.org/10.1029/2011WR010383

Maillard, P., Alencar-Silva, T., 2013. A method for delineating riparian forests using region-based image classification and depth-to-water analysis. Int. J. Remote Sens. 34, 7991-8010. https://doi.org/10.1080/01431161.2013.827847

Manfreda, S., McCabe, M.F., Miller, P.E., Lucas, R., Pajuelo Madrigal, V., Mallinis, G., Ben Dor, E., Helman, D., Estes, L., Ciraolo, G., Müllerová, J., Tauro, F., De Lima, M.I., De Lima, J.L.M.P., Maltese, A., Frances, F., Caylor, K., Kohv, M., Perks, M., Ruiz-Pérez, G., Su, Z., Vico, G., Toth, B., 2018. On the Use of Unmanned Aerial Systems for Environmental Monitoring. Remote Sens. 10, 641. https://doi.org/10.3390/rs10040641

Manners, R., Schmidt, J., Wheaton, J.M., 2013. Multiscalar model for the determination of spatially explicit riparian vegetation roughness. J. Geophys. Res. Earth Surf. 118, 65-83. https://doi.org/10.1029/2011JF002188

Marcus, W.A., Fonstad, M.A., 2008. Optical remote mapping of rivers at sub-meter resolutions and watershed extents. Earth Surf. Process. Landf. 33, 4-24. https://doi.org/10.1002/esp.1637 Martin, F.-M., Müllerová, J., Borgniet, L., Dommanget, F., Breton, V., Evette, A., 2018. Using Singleand Multi-Date UAV and Satellite Imagery to Accurately Monitor Invasive Knotweed Species. Remote Sens. 10, 1662. https://doi.org/10.3390/rs10101662

Matsuura, T., Suzuki, W., 2013. Analysis of topography and vegetation distribution using a digital elevation model: case study of a snowy mountain basin in northeastern Japan. Landsc. Ecol. Eng. 9, 143-155. https://doi.org/10.1007/s11355-012-0187-2 
Miao, X., Patil, R., Heaton, J.S., Tracy, R.C., 2011. Detection and classification of invasive saltcedar through high spatial resolution airborne hyperspectral imagery. Int. J. Remote Sens. 32, 2131-2150. https://doi.org/10.1080/01431161003674618

Michez, A., Piégay, H., Lisein, J., Claessens, H., Lejeune, P., 2016a. Mapping of riparian invasive species with supervised classification of Unmanned Aerial System (UAS) imagery. Int. J. Appl. Earth Obs. Geoinformation 44, 88-94. https://doi.org/10.1016/j.jag.2015.06.014

Michez, A., Piégay, H., Lisein, J., Claessens, H., Lejeune, P., 2016b. Classification of riparian forest species and health condition using multi-temporal and hyperspatial imagery from unmanned aerial system. Environ. Monit. Assess. 188, 146. https://doi.org/10.1007/s10661-015-4996-2

Michez, A., Piégay, H., Lejeune, P., Claessens, H., 2017. Multi-temporal monitoring of a regional riparian buffer network ( $>12,000 \mathrm{~km})$ with LiDAR and photogrammetric point clouds. J. Environ. Manage. 202, 424-436. https://doi.org/10.1016/j.jenvman.2017.02.034

Morgan, J.L., Gergel, S.E., Coops, N.C., 2010. Aerial Photography: A Rapidly Evolving Tool for Ecological Management. BioScience 60, 47-59. https://doi.org/10.1525/bio.2010.60.1.9

Muller, E., Décamps, H., Dobson, M.K., 1993. Contribution of space remote sensing to river studies. Freshw. Biol. 29, 301-312. https://doi.org/10.1111/j.1365-2427.1993.tb00766.x

Munné, A., Prat, N., Solà, C., Bonada, N., Rieradevall, M., 2003. A simple field method for assessing the ecological quality of riparian habitat in rivers and streams: QBR index. Aquat. Conserv. Mar. Freshw. Ecosyst. 13, 147-163. https://doi.org/10.1002/aqc.529

Nagler, P.L., Brown, T., Hultine, K.R., van Riper, C., Bean, D.W., Dennison, P.E., Murray, R.S., Glenn, E.P., 2012. Regional scale impacts of Tamarix leaf beetles (Diorhabda carinulata) on the water availability of western U.S. rivers as determined by multi-scale remote sensing methods. Remote Sens. Environ. 118, 227-240. https://doi.org/10.1016/j.rse.2011.11.011

Nagler, P.L., Doody, T.M., Glenn, E.P., Jarchow, C.J., Barreto-Muñoz, A., Didan, K., 2016. Wide-area estimates of evapotranspiration by red gum (Eucalyptus camaldulensis) and associated 
vegetation in the Murray-Darling River Basin, Australia. Hydrol. Process. 30, 1376-1387. https://doi.org/10.1002/hyp.10734

Naiman, R.J., Décamps, H., 1997. The Ecology of Interfaces: Riparian Zones. Annu. Rev. Ecol. Syst. 28, 621-658. https://doi.org/10.1146/annurev.ecolsys.28.1.621

1110

1111

1112

1113

Naiman, R.J., Decamps, H., McClain, M.E., 2005. Riparia: Ecology, Conservation, and Management of Streamside Communities. Elsevier.

Nardi, F., Annis, A., Di Baldassarre, G., Vivoni, E.R., Grimaldi, S., 2019. GFPLAIN250m, a global highresolution dataset of Earth's floodplains. Sci. Data 6, 180309. https://doi.org/10.1038/sdata.2018.309

Narumalani, S., Mishra, D.R., Wilson, R., Reece, P., Kohler, A., 2009. Detecting and Mapping Four Invasive Species along the Floodplain of North Platte River, Nebraska. Weed Technol. 23, 99107. https://doi.org/10.1614/WT-08-007.1

National Research Council, 2002. Riparian Areas: Functions and Strategies for Management. Washington (DC): National Academies Press. https://doi.org/10.17226/10327

Palmquist, E.C., Ralston, B.E., Merritt, D.M., Shafroth, P.B., 2018. Landscape-scale processes influence riparian plant composition along a regulated river. J. Arid Environ. 148, 54-64. https://doi.org/10.1016/j.jaridenv.2017.10.001

Parent, J.R., Volin, J.C., Civco, D.L., 2015. A fully-automated approach to land cover mapping with airborne LiDAR and high resolution multispectral imagery in a forested suburban landscape. ISPRS J. Photogramm. Remote Sens. 104, 18-29. https://doi.org/10.1016/j.isprsjprs.2015.02.012

Peerbhay, K., Mutanga, O., Lottering, R., Ismail, R., 2016. Mapping Solanum mauritianum plant invasions using WorldView-2 imagery and unsupervised random forests. Remote Sens. Environ. 182, 39-48. https://doi.org/10.1016/j.rse.2016.04.025 
Penning, E., 2018. Interactions between flow and vegetation: Translating knowledge from academic research to daily water management. E3S Web Conf. 40, 01001. https://doi.org/10.1051/e3sconf/20184001001

Piégay, H., Landon, N., 1997. Promoting ecological management of riparian forests on the Drôme River, France. Aquat. Conserv. Mar. Freshw. Ecosyst. 7, 287-304. https://doi.org/10.1002/(SICI)1099-0755(199712)7:4<287::AID-AQC247>3.0.CO;2-S

Piégay, H., Arnaud, F., Belletti, B., Bertrand, M., Bizzi, S., Carbonneau, P., Dufour, S., Liébault, F., RuizVillanueva, V., \& Slater, L., 2020. Remotely sensed rivers in the Anthropocene: State of the art and prospects. Earth Surface Processes and Landforms, 45(1), 157-188. https://doi.org/10.1002/esp.4787

Poff, B., Koestner, K. A., Neary, D. G., \& Henderson, V., 2011. Threats to Riparian Ecosystems in Western North America: An Analysis of Existing Literature1. JAWRA Journal of the American Water Resources Association, 47(6), 1241-1254. https://doi.org/10.1111/j.17521688.2011.00571.x

Pontius, R.G.J., Millones, M., 2011. Death to Kappa: birth of quantity disagreement and allocation disagreement for accuracy assessment. Int. J. Remote Sens. 32, 4407-4429. https://doi.org/10.1080/01431161.2011.552923

Poole, G.C., Berman, C.H., 2001. An Ecological Perspective on In-Stream Temperature: Natural Heat Dynamics and Mechanisms of Human-CausedThermal Degradation. Environ. Manage. 27, 787-802. https://doi.org/10.1007/s002670010188

Rajão, R., 2013. Representations and discourses: the role of local accounts and remote sensing in the formulation of Amazonia's environmental policy. Environ. Sci. Policy, SI: Environmental and Developmental Discourses: Technical knowledge, discursive spaces and politics 30, 60-71. https://doi.org/10.1016/j.envsci.2012.07.019 
Rapinel, S., Mony, C., Lecoq, L., Clément, B., Thomas, A., Hubert-Moy, L., 2019. Evaluation of Sentinel-2 time-series for mapping floodplain grassland plant communities. Remote Sens. Environ. 223, 115-129. https://doi.org/10.1016/j.rse.2019.01.018

Richardson, D.M., Holmes, P.M., Esler, K.J., Galatowitsch, S.M., Stromberg, J.C., Kirkman, S.P., Pyšek, P., Hobbs, R.J., 2007. Riparian vegetation: degradation, alien plant invasions, and restoration prospects. Divers. Distrib. 13, 126-139. https://doi.org/10.1111/j.1366-9516.2006.00314.x

Richardson, J.J., Moskal, L.M., Kim, S.-H., 2009. Modeling approaches to estimate effective leaf area index from aerial discrete-return LIDAR. Agric. For. Meteorol. 149, 1152-1160. https://doi.org/10.1016/j.agrformet.2009.02.007

Richardson, J.J., Torgersen, C.E., Moskal, L.M., 2019. Lidar-based approaches for estimating solar insolation in heavily forested streams. Hydrol. Earth Syst. Sci. 23, 2813-2822. https://doi.org/10.5194/hess-23-2813-2019

Richter, R., Reu, B., Wirth, C., Doktor, D., Vohland, M., 2016. The use of airborne hyperspectral data for tree species classification in a species-rich Central European forest area. Int. J. Appl. Earth Obs. Geoinformation 52, 464-474. https://doi.org/10.1016/j.jag.2016.07.018

Riedler, B., Pernkopf, L., Strasser, T., Lang, S., Smith, G., 2015. A composite indicator for assessing habitat quality of riparian forests derived from Earth observation data. Int. J. Appl. Earth Obs. Geoinformation, Special Issue on Earth observation for habitat mapping and biodiversity monitoring 37, 114-123. https://doi.org/10.1016/j.jag.2014.09.006

Rijkswaterstaat, 2014. Vegetatielegger : instrument voor veilige en natuurlijke uiterwaarden.

Rood, S.B., Braatne, J.H., Goater, L.A., 2010. Responses of obligate versus facultative riparian shrubs following river damming. River Res. Appl. 26, 102-117. https://doi.org/10.1002/rra.1246

Rubol, S., Ling, B., Battiato, I., 2018. Universal scaling-law for flow resistance over canopies with complex morphology. Sci. Rep. 8, 1-15. https://doi.org/10.1038/s41598-018-22346-1 
Rutherford, J.C., Meleason, M.A., Davies-Colley, R.J., 2018. Modelling stream shade: 2. Predicting the effects of canopy shape and changes over time. Ecol. Eng. 120, 487-496. https://doi.org/10.1016/j.ecoleng.2018.07.008

Sá, C., Grieco, J., 2016. Open Data for Science, Policy, and the Public Good. Rev. Policy Res. 33, 526543. https://doi.org/10.1111/ropr.12188

Sankey, T.T., Sankey, J.B., Horne, R., Bedford, A., 2016. Remote Sensing of Tamarisk Biomass, Insect Herbivory, and Defoliation: Novel Methods in the Grand Canyon Region, Arizona [WWW Document]. https://doi.org/info:doi/10.14358/PERS.82.8.645

Scott, M.L., Nagler, P.L., Glenn, E.P., Valdes-Casillas, C., Erker, J.A., Reynolds, E.W., Shafroth, P.B., Gomez-Limon, E., Jones, C.L., 2009. Assessing the extent and diversity of riparian ecosystems in Sonora, Mexico. Biodivers. Conserv. 18, 247-269. https://doi.org/10.1007/s10531-008$9473-6$

Seddon, J.A., Zerger, A., Doyle, S.J., Briggs, S.V., 2007. The extent of dryland salinity in remnant woodland and forest within an agricultural landscape. Aust. J. Bot. 55, 533-540. https://doi.org/10.1071/BT06100

Shendryk, I., Broich, M., Tulbure, M.G., McGrath, A., Keith, D., Alexandrov, S.V., 2016. Mapping individual tree health using full-waveform airborne laser scans and imaging spectroscopy: A case study for a floodplain eucalypt forest. Remote Sens. Environ. 187, 202-217. https://doi.org/10.1016/j.rse.2016.10.014

Shields, F.D., Coulton, K.G., Nepf, H., 2017. Representation of Vegetation in Two-Dimensional Hydrodynamic Models. J. Hydraul. Eng. 143, 02517002. https://doi.org/10.1061/(ASCE)HY.1943-7900.0001320

Sims, N.C., Colloff, M.J., 2012. Remote sensing of vegetation responses to flooding of a semi-arid floodplain: Implications for monitoring ecological effects of environmental flows. Ecol. Indic. 18, 387-391. https://doi.org/10.1016/j.ecolind.2011.12.007 
Solins, J.P., Thorne, J.H., Cadenasso, M.L., 2018. Riparian canopy expansion in an urban landscape: Multiple drivers of vegetation change along headwater streams near Sacramento, California. Landsc. Urban Plan. 172, 37-46. https://doi.org/10.1016/j.landurbplan.2017.12.005

Sridhar, B.B.M., Vincent, R.K., Clapham, W.B., Sritharan, S.I., Osterberg, J., Neale, C.M.U., Watts, D.R., 2010. Mapping saltcedar (Tamarix ramosissima) and other riparian and agricultural vegetation in the Lower Colorado River region using multi-spectral Landsat TM imagery. Geocarto Int. 25, 649-662. https://doi.org/10.1080/10106049.2010.521857

Staben, G.W., Evans, K.G., 2008. Estimates of tree canopy loss as a result of Cyclone Monica, in the Magela Creek catchment northern Australia. Austral Ecol. 33, 562-569. https://doi.org/10.1111/j.1442-9993.2008.01911.x

Starkey, E. N., 2016. Upper Columbia Basin Network stream channel characteristics and riparian condition annual report 2013: John Day Fossil Beds National Monument (JODA). Natural Resource Data Series NPS/UCBN/NRDS-2015/808. National Park Service, Fort Collins, Colorado.

Steiniger, S., Hay, G.J., 2009. Free and open source geographic information tools for landscape ecology. Ecol. Inform. 4, 183-195. https://doi.org/10.1016/j.ecoinf.2009.07.004

Stella, J.C., Bendix, J., 2019. Chapter 5 - Multiple Stressors in Riparian Ecosystems, in: Sabater, S., Elosegi, A., Ludwig, R. (Eds.), Multiple Stressors in River Ecosystems. Elsevier, pp. 81-110. https://doi.org/10.1016/B978-0-12-811713-2.00005-4

Stöcker, C., Bennett, R., Nex, F., Gerke, M., Zevenbergen, J., 2017. Review of the Current State of UAV Regulations. Remote Sens. 9, 459. https://doi.org/10.3390/rs9050459

Straatsma, M.W., Baptist, M.J., 2008. Floodplain roughness parameterization using airborne laser scanning and spectral remote sensing. Remote Sens. Environ. 112, 1062-1080. https://doi.org/10.1016/j.rse.2007.07.012 
Straatsma, M.W., Kleinhans, M.G., 2018. Flood hazard reduction from automatically applied landscaping measures in RiverScape, a Python package coupled to a two-dimensional flow model. Environ. Model. Softw. 101, 102-116. https://doi.org/10.1016/j.envsoft.2017.12.010

Straatsma, M.W., Fliervoet, J.M., Kabout, J.A.H., Baart, F., Kleinhans, M.G., 2019. Towards multiobjective optimization of large-scale fluvial landscaping measures. Nat. Hazards Earth Syst. Sci. 19, 1167-1187. https://doi.org/10.5194/nhess-19-1167-2019

Strasser, T., Lang, S., 2015. Object-based class modelling for multi-scale riparian forest habitat mapping. Int. J. Appl. Earth Obs. Geoinformation 37, 29-37.

Tabacchi, E., Correll, D.L., Hauer, R., Pinay, G., Planty-Tabacchi, A.-M., Wissmar, R.C., 1998. Development, maintenance and role of riparian vegetation in the river landscape. Freshw. Biol. 40, 497-516. https://doi.org/10.1046/j.1365-2427.1998.00381.x

Tillack, A., Clasen, A., Kleinschmit, B., Förster, M., 2014. Estimation of the seasonal leaf area index in an alluvial forest using high-resolution satellite-based vegetation indices. Remote Sens. Environ. 141, 52-63. https://doi.org/10.1016/j.rse.2013.10.018

Tompalski, P., Coops, N.C., White, J.C., Wulder, M.A., Yuill, A., 2017. Characterizing streams and riparian areas with airborne laser scanning data. Remote Sens. Environ. 192, 73-86. https://doi.org/10.1016/j.rse.2017.01.038

Tomsett, C., Leyland, J., 2019. Remote sensing of river corridors: A review of current trends and future directions. River Res. Appl. 35, 779-803. https://doi.org/10.1002/rra.3479

Tormos, T., Kosuth, P., Durrieu, S., Villeneuve, B., Wasson, J.G., 2011. Improving the quantification of land cover pressure on stream ecological status at the riparian scale using High Spatial Resolution Imagery. Phys. Chem. Earth Parts ABC 36, 549-559.

Townsend, P.A., Walsh, S.J., 2001. Remote sensing of forested wetlands: application of multitemporal and multispectral satellite imagery to determine plant community composition and structure in southeastern USA. Plant Ecol. 157, 129-149. https://doi.org/10.1023/A:1013999513172 
Townsend, P.A., 2002. Relationships between forest structure and the detection of flood inundation in forested wetlands using C-band SAR. Int. J. Remote Sens. 23, 443-460. https://doi.org/10.1080/01431160010014738

Turner, M.D., Taylor, P.J., 2003. Critical Reflections on the Use of Remote Sensing and GIS Technologies in Human Ecological Research. Hum. Ecol. 31, 177-182. https://doi.org/10.1023/A:1023958712140

Turner, W., Rondinini, C., Pettorelli, N., Mora, B., Leidner, A.K., Szantoi, Z., Buchanan, G., Dech, S., Dwyer, J., Herold, M., Koh, L.P., Leimgruber, P., Taubenboeck, H., Wegmann, M., Wikelski, M., Woodcock, C., 2015. Free and open-access satellite data are key to biodiversity conservation. Biol. Conserv. 182, 173-176. https://doi.org/10.1016/j.biocon.2014.11.048

Vande Kamp, K., Rigge, M., Troelstrup, N.H., Smart, A.J., Wylie, B., 2013. Detecting Channel Riparian Vegetation Response to Best-Management-Practices Implementation in Ephemeral Streams With the Use of Spot High-Resolution Visible Imagery. Rangel. Ecol. Manag. 66, 63-70. https://doi.org/10.2111/REM-D-11-00153.1

Vanden Borre, J., Paelinckx, D., Mücher, C.A., Kooistra, L., Haest, B., De Blust, G., Schmidt, A.M., 2011. Integrating remote sensing in Natura 2000 habitat monitoring: Prospects on the way forward. J. Nat. Conserv. 19, 116-125. https://doi.org/10.1016/j.jnc.2010.07.003

Varga, K., Dévai, G., Tóthmérész, B., 2013. Land use history of a floodplain area during the last 200 years in the Upper-Tisza region (Hungary). Reg. Environ. Change 13, 1109-1118. https://doi.org/10.1007/s10113-013-0424-8

Vaz, A.S., Alcaraz-Segura, D., Campos, J.C., Vicente, J.R., Honrado, J.P., 2018. Managing plant invasions through the lens of remote sensing: A review of progress and the way forward. Sci. Total Environ. 642, 1328-1339. https://doi.org/10.1016/j.scitotenv.2018.06.134

Verry, E.S., Dolloff, C.A., Manning, M.E., 2004. Riparian ecotone: A functional definition and delineation for resource assessment. Water Air Soil Pollut. Focus 4, 67-94. https://doi.org/10.1023/B:WAFO.0000012825.77300.08 
Vivier, A., Breton, L., Grivel, S., Melun, G., Piégay, H., Demarchi, L., Adrien, M., Séjour, A., Thommeret, N., Tormos, T., Cazals, C., Koehl, M., Lague, D., Rapinel, S., Ville, A., Chevillier, B., Tarrío, D., Guerri, O., Laslier, M., Dupont, P., 2018. Actes de la journée technique "Avancées, apports et perspectives de la télédétection pour la caractérisation physique des corridors fluviaux ".

Vollmer, D., Prescott, M. F., Padawangi, R., Girot, C., \& Grêt-Regamey, A., 2015. Understanding the value of urban riparian corridors: Considerations in planning for cultural services along an Indonesian river. Landscape and Urban Planning, 138, 144-154. https://doi.org/10.1016/j.landurbplan.2015.02.011

Wagner-Lücker, I., Lanz, E., Förster, M., Janauer, G.A., Reiter, K., 2013. Knowledge-based framework for delineation and classification of ephemeral plant communities in riverine landscapes to support EC Habitat Directive assessment. Ecol. Inform., The analysis and application of spatial ecological data to support the conservation of biodiversity $14,44-47$. https://doi.org/10.1016/j.ecoinf.2012.11.003

Wallace, C.S.A., Villarreal, M.L., lii, C. van R., 2013. Influence of monsoon-related riparian phenology on yellow-billed cuckoo habitat selection in Arizona. J. Biogeogr. 40, 2094-2107. https://doi.org/10.1111/jbi.12167

Wan, Y., Wan, C., Hedgepeth, M., 2015. Elucidating multidecadal saltwater intrusion and vegetation dynamics in a coastal floodplain with artificial neural networks and aerial photography. Ecohydrology 8, 309-324. https://doi.org/10.1002/eco.1509

Wang, L., Silván-Cárdenas, J.L., Yang, J., Frazier, A.E., 2013. Invasive Saltcedar (Tamarisk spp.) Distribution Mapping Using Multiresolution Remote Sensing Imagery. Prof. Geogr. 65, 1-15. https://doi.org/10.1080/00330124.2012.679440

Wasser, L., Chasmer, L., Day, R., Taylor, A., 2015. Quantifying land use effects on forested riparian buffer vegetation structure using LiDAR data. Ecosphere 6, art10. https://doi.org/10.1890/ES14-00204.1 
Wawrzyniak, V., Allemand, P., Bailly, S., Lejot, J., Piégay, H., 2017. Coupling LiDAR and thermal imagery to model the effects of riparian vegetation shade and groundwater inputs on summer river temperature. Sci. Total Environ. 592, 616-626. https://doi.org/10.1016/j.scitotenv.2017.03.019

Weissteiner, C.J., Ickerott, M., Ott, H., Probeck, M., Ramminger, G., Clerici, N., Dufourmont, H., De Sousa, A.M.R., 2016. Europe's Green Arteries-A Continental Dataset of Riparian Zones. Remote Sens. 8, 925. https://doi.org/10.3390/rs8110925

Willaarts, B., Ballesteros, M., \& Hernández-Mora, N., 2014. Ten years of the Water Framework Directive in Spain: An overview of the ecological and chemical status of surface water bodies. In P. Martinez-Santos, M. Aldaya, M. Llamas, \& L. Thuy (Eds.), Integrated Water Resources Management in the 21st Century: Revisiting the paradigm (pp. 99-120). CRC Press. https://doi.org/10.1201/b16591-10

Wohl, E., 2017. Bridging the gaps: An overview of wood across time and space in diverse rivers. Geomorphology, Dynamics and ecology of Wood in World Rivers 279, 3-26. https://doi.org/10.1016/j.geomorph.2016.04.014

Wohl, E., Bledsoe, B.P., Fausch, K.D., Kramer, N., Bestgen, K.R., Gooseff, M.N., 2016. Management of Large Wood in Streams: An Overview and Proposed Framework for Hazard Evaluation. JAWRA J. Am. Water Resour. Assoc. 52, 315-335. https://doi.org/10.1111/1752-1688.12388

Wulder, M.A., White, J.C., Nelson, R.F., Næsset, E., Ørka, H.O., Coops, N.C., Hilker, T., Bater, C.W., Gobakken, T., 2012. Lidar sampling for large-area forest characterization: A review. Remote Sens. Environ. 121, 196-209. https://doi.org/10.1016/j.rse.2012.02.001

Yang, X., 2007. Integrated use of remote sensing and geographic information systems in riparian vegetation delineation and mapping. Int. J. Remote Sens. 28, 353-370. https://doi.org/10.1080/01431160600726763 
Yousefi, S., Mirzaee, S., Keesstra, S., Surian, N., Pourghasemi, H. R., Zakizadeh, H. R., \& Tabibian, S., 2018. Effects of an extreme flood on river morphology (case study: Karoon River, Iran). Geomorphology, 304, 30-39. https://doi.org/10.1016/j.geomorph.2017.12.034

Zahidi, I., Yusuf, B., Cope, M., Ahmed Mohamed, T., Mohd Shafri, H.Z., 2018. Effects of depth-varying vegetation roughness in two-dimensional hydrodynamic modelling. Int. J. River Basin Manag. 16, 413-426. https://doi.org/10.1080/15715124.2017.1394313

Zaimes, G. N., Schultz, R. C., \& Isenhart, T. M., 2004. Stream bank erosion adjacent to riparian forest buffers, row-crop fields, and continuously-grazed pastures along Bear Creek in central lowa. Journal of Soil and Water Conservation, 59(1), 19-27.

Zaimes, G. N., Gounaridis, D., \& Symenonakis, E., 2019. Assessing the impact of dams on riparian and deltaic vegetation using remotely-sensed vegetation indices and Random Forests modelling. Ecological Indicators, 103, 630-641. https://doi.org/10.1016/j.ecolind.2019.04.047

Zogaris, S., Markogianni, V., Özeren, S.C., Dimitriou, E., 2015. Assessment of riparian zone and river island conditions in a trans-boundary greenbelt: the Evris/Meriç River (Greece - Turkey). Fresenius Environ. Bull. 24, 10. 